\title{
INTRODUCTION
}

Lithic miniaturization refers to the systematic production and use of small tools from small cores. Demonstrating the intent to miniaturize toolkits is critical in distinguishing intentional versus accidental small tool production. This can be achieved by showing purposeful raw material selection for small core production, systematic technological intent to miniaturize production, and by conduction use-trace analyses on the resulting flakes. A fourth factor involves the use of middle range theoretical models derived from experimental and/or ethnographic research to demonstrate the use of small tools and cores. These middle range models guide discussions about why humans choose to miniaturize lithic production.

Lithic miniaturization is a truly global phenomenon increasing during the Late Pleistocene in many regions of the Old World from Africa to East Asia (Elston and Kuhn 2002). By the Holocene, small stone tools were regular components of hunter-gatherer toolkits in Australia, Northern Asia and North America. Because lithic miniaturization (also sometimes called 'microlithization') proliferated during the Late Pleistocene and the Later Stone Age (LSA), archaeologists associate it with 'modern human behavior' (e.g. McBrearty and Brooks, 2000). However, lithic miniaturization is no more consistent a feature of Late Pleistocene assemblages than pointed bone production, rock art or engraved ochre. Lithic miniaturization was one of our Pleistocene ancestor's many strategic options for making stone tools.

Lithic miniaturization remains one of the most economically consequential developments in Pleistocene lithic technology (Hiscock 2015b). Small tool technologies enabled humans to extract usable cutting edges from raw materials more effectively and efficiently and to do so on a wide range of rock types (Bamforth and Bleed 1997). Humans used multiple technological strategies for lithic miniaturization in various parts of the world, ranging from specialized pressure-based techniques to simpler bipolar techniques (Elston and Brantingham 2002; Desrosiers 2012; de la Peña 2015a). These strategies provided a range of flexible technological solutions to the problems posed by migration and diffusion into new territories (e.g. North America) and to the maintenance of these territories once established (e.g. East Africa) (Madsen 
2004; Eren et al. 2012). That lithic miniaturization proliferated during the Late Pleistocene suggests a relationship between these small technologies and the effects on human demography, subsistence, and mobility posed by the hyper variable climates of this period (e.g. Mitchell 1990; Elston and Brantingham 2002; Petraglia et al. 2009).

Humans likely adopted lithic miniaturization in response to multiple variables, including its technological costs and benefits, cultural choices, and ecological factors (Hiscock 2015b). For example, lithic miniaturization increased during the Late Pleistocene in South East Asia under conditions of population pressure and ecological risk (Petraglia et al. 2009), while in South West Asia their production during the terminal Pleistocene and early Holocene appears linked more to increasingly sedentary lifestyles and other social and technological changes that occurred during the transitions to food production (Neeley 2002). In Australia, conflict, isochestric style and ecological factors all appear to have influenced human choices to miniaturize their lithic toolkits (Hiscock 1994; McDonald et al. 2007). This complexity calls for a contextual approach to understanding lithic miniaturization; one focused on understanding its strategic benefits and costs.

\section{The problems with 'microliths'}

Microliths are the most visible remnants of Pleistocene technological miniaturization (see Elston and Kuhn 2002 and papers therein). The term microlith was originally created to describe the more generalized production of small retouched tools or 'pygmy' implements (Mortillet 1896, Abott 1909). This definition formed the basis of the widely used Mode 5 microlithic as defined by G. Clark (1969) (see Table 1). Many archaeologists still adhere to this definition, but place emphasis on the production of backed geometric tools (e.g. segments, triangles, trapezoids) (e.g. Mellars 2006). Some researchers (e.g. Straus 2002: 70-71) distinguish between microliths:

"Any small (2-3cm long, but often even shorter) stone artifact deliberately retouched by means of vertical ("backing") or glancing (normal) percussion or pressure work, either direct or indirect, with or without anvil." 
and geometric microliths:

"Geometric microliths are specialized subset of the overall category, consisting of standardized forms (semicircles, rectangles, isosceles and scalene triangles, rhomboids, trapezoids) that are generally made on bladelets that have been segmented (often with the "microburin" or truncation notch + snap method)."

D. Clark's (1985: 95) is a broader and more inclusive definition of a microlithic assemblage:

"Microlithic industries are those in which the mode for the flaked stone tool equipment is based on the manufacture of bladelets and flakelets the maximum length of which does not exceed 50 $\mathrm{mm}$ and the great majority are under $30 \mathrm{~mm}$ long. Such industries are characterized by varying proportions of backed tools and small convex scrapers."

Kuhn \& Elston (2002: 2) largely restrict their definition of microlithic assemblages to the production of bladelets, some of which were retouched into standardized tool forms. For them, bladelets must occur in high frequencies to signal a microlithic strategy. Yet, determining the exact frequency of bladelets necessary to constitute a microlithic assemblage is a subjective exercise (cf. Pargeter and Redondo 2015). Others consider the conflation of microblade and microlith (small retouched tools made on bladelets and flakes) a disjunction, and argue instead for the two to be considered separately (e.g. Mishra et al. 2013; Lewis 2015). Backing, or blunting, is widely considered a hallmark of microlithic strategies (Leakey 1931), even where these backed tools are relatively large (> $60 \mathrm{~mm}$ ) (Hiscock 2002). Many microlithic assemblages such as those of the Levantine Upper Paleolithic are generally not backed, but are still considered microlithic by virtue of their small size and/or micro-retouch (Belfer-Cohen and Goring-Morris 2002).

\section{TABLE 1: MICROLITH DEFINTIONS AND SIZES}

While archaeologists agree that the modification of flakes and bladelets into geometric forms constitutes a clear example of 'microlithization', few agree on how small micro is (see Table 1). 
In East Africa, archaeologists consider the modification of long flakes (50 - $100 \mathrm{~mm})$ via backing enough to signal a microlithic strategy (Ambrose 2002). Southern African Howieson's Poort assemblages are traditionally considered microlithic by virtue of their distinctive large (> $36 \mathrm{~mm}$ length) geometric backed tools, with smaller examples (< $17 \mathrm{~mm}$ length) considered a unique case (Wadley and Mohapi 2008). 'Micro'-blade cores from Siberia and Alaska are on average between 30 and $50 \mathrm{~mm}$ in length, which is at least three times larger than the small bladelet cores found across southern Africa during the Late and terminal Pleistocene (Mitchell 2002). Clearly no universal size cut-off can accurately describe the boundary between macro and micro lithic technologies in all archaeological contexts.

Microlithic strategies are also not uniform in their technology. Recently, Lewis (2015) has documented how Late Pleistocene lithic miniaturization strategies in South Asia and southern Africa differed in terms of the the tools selected for retouch, core reduction techniques, and raw material selection. Her reanalysis of the microlithic Howieson's Poort assemblages from Rose Cottage Cave and Umhlatuzana in South Africa has shown that geometric backed microliths, despite being the fossil directeur for the Howieson's Poort, are a numerical inferior component of the small retouched tools at both sites (Lewis 2015). Recent reanalysis of the Grey Sand layers at Sibudu Cave $(63.8 \pm 2.5 \mathrm{ka})$ has broadened its microlithic component to include the systematic production and use of small flakes and bladelets some of which were made using a bipolar technique (de la Peña and Wadley 2014). When explaining 'microlithization' or lithic miniaturization more broadly, archaeologists are not always referring to the same thing, either typologically or technologically.

In southern Africa lithic assemblages are labelled 'microlithic' either because they are small, or because they have backed tools. After c. 44 ka calBP southern African lithic assemblages are considered microlithic by virtue of the systematic production of small (<25 mm length and 12 mm width) unretouched flakes and bladelets from small cores (e.g. Mitchell 1994; Mackay et al. 2015; Villa et al. 2012; Wadley 1993; cf. J. Deacon 1984). Few, if any, of these tools were retouched while many of them do show signs of having been used (e.g. Binneman 1997; Binneman and Mitchell 1997). The following case study demonstrates what such an assemblage 
looks like and highlights the role played by small unretouched tools in processes of lithic miniaturization across the southern African region.

\section{FIGURE 1: NTLOANA TŠOANA MAP AND RAW MATERIAL SURVEY MAP}

\section{OVERVIEW OF THE NTLOANA TŠOANA LITHIC ASSEMBLAGE}

Ntloana Tšoana lies in the broader summer rainfall Grassland Biome at the intersection between the mixed to sour grasslands to the west and the Alpine environments of the Maloti Mountains to the east (Arthur and Mitchell 2012). The site is situated in the Maseru District of western Lesotho approx. $1600 \mathrm{~m}$ a.s.l. and was along the banks of the Phuthiatsana River until recently being submerged as a result of construction of the Metolong Dam (Arthur and Mitchell 2012; see Figure 1). Geological surveys show that the site is in an environment rich in fine grained silicate rocks (e.g. chert, agate, chalcedony) as well as crystal quartz (see Figure 1). Mitchell and Steinberg (1992) initially conducted test excavations at Ntloana Tšoana in 1989 with more recent work led by Arthur between 2009 - 12 (Arthur and Mitchell 2012) (see Figure 2). Arthur's excavations were especially fine-grained with a total of 758 stratigraphic units excavated over an area of $13 \mathrm{~m}^{2}$ (Mitchell and Arthur 2010).

Ntloana Tšoana contains a series of rich terminal Pleistocene human occupations referred to collectively as Phase 5 and bracketed by four ${ }^{14} \mathrm{C}$ dates to $14-13 \mathrm{ka}$ calBP (Arthur and Mitchell 2012) (see Table 2). The Phase 5 occupations comprise a series of compact charcoal and ashrich silts between 13 and $20 \mathrm{~cm}$ thick, which include extensive microstratified hearth features (C. Arthur pers. comm, see Figure 2). Overlying these deposits are a series of early Holocene occupations dating to between 11-9.5 ka calBP, and underlying them is a Middle Stone Age (MSA) unit dated to between 61 - 59 ka (Mitchell and Steinberg 1992; Jacobs et al. 2008; (2015)) (see Figure 2). This paper focuses on the lithics from Phase 5.

The Phase 5 lithic assemblage comprises chert, agate, and chalcedony with crystal quartz occupying a small, but distinct, component. The dominant technological organization is towards the production of small flakes and bladelets. These small unretouched tools went un-recognized 
during the 1989 excavations and in the initial analysis of the assemblage (Mitchell 1993; Mitchell pers. comm). Likely explanations for this oversight are that it was standard practice across southern Africa to measure only lithic material over $20 \mathrm{~mm}$ in length and to count material under $20 \mathrm{~mm}$ in length only if it was a recognizable 'bladelet' (see J. Deacon 1984). Moreover, researchers at that time were not trained to recognize bipolar technology, which meant small flakes and bladelets produced in this manner were analytically invisible.

\section{FIGURE 2: NTLOANA TŠOANA EXCAVATION SECTIONS AND PLAN}

The ${ }^{14} \mathrm{C}$ dates place the Phase 5 lithic assemblage towards the end of the Late Pleistocene microlithic phase of the southern African LSA and within its Robberg technocomplex (Mitchell 2002). Robberg assemblages are considered microlithic because they preserve evidence for systematic bladelet and small flake production (J. Deacon 1984; Wadley 1996; A. M. B. Clark 1999; Mitchell 2002). Robberg bladelets and flakes had a variety of functions with the majority of them used unretouched (Binneman 1997; Binneman and Mitchell 1997). In southern Africa, archaeologists use the Robberg technocomplex, and its predecessor in the early LSA, to mark the onset of the Late Pleistocene LSA, as a microlithic pattern distinct from the generally flakedominated toolkits of the MSA (H. J. Deacon and Deacon 1999; but see Lombard et al. 2012; Mitchell 2002).

\section{TABLE 2: NTLOANA TŠOANA DATES}

\section{SAMPLE AND METHODS}

Lithic core and flake size depends on a range of contextual factors, such as raw material variability/availability, reduction strategies, knapping traditions, and functional variability. For these reasons, contextual approaches to determining 'large' and 'small' are preferred to universal size cut-offs (see Pargeter \& Redondo 2015 for an example). K-means cluster analyses (e.g. D. Kaufman 1986) were used to sort the Ntloana Tšoana cores and flakes into large and small size classes (see Figure 3). K-means clustering divides $n$ data observations into $k$ clusters in a recursive process, with each observation assigned a cluster containing its closest mean value and 
reducing the overall Euclidean distance between assigned points (L. Kaufman and Rousseeuw 2009). This way, similar sized artefacts are clustered together with the process being repeated for artefacts in each layer at each site. In this analysis, continuous data (maximum length, width and mass) were used to determine core and flake size clustering. Deciding how many clusters to retain from a cluster analysis requires an element of visual subjectivity, but this remains a common method for determining the number of components to extract from a dataset (Cattell and Vogelmann 1977). Statistical simulation studies have shown that when component or cluster loading is higher, identification of the 'correct' number of components is more accurate (Kanyongo 2005). These methods provide a more objective and assemblage specific approach to identifying data clusters than arbitrary universal size cut-offs.

\section{FIGURE 3: CLUSTER ANALYSIS CORES AND FLAKES}

\section{Background to the Ntloana Tšoana lithic sample and the lithic analysis}

This study focuses on a sample of the Ntloana Tšoana lithic assemblage derived from one of the

site's $1 \mathrm{~m}^{2}$ excavation areas, square 4853. Analyzed material from this square derive from 17 excavated contexts representing various hearths, burning events and aeolian deposits. These Phase 5 contexts are directly equivalent and adjacent to the 030-032 BLOS layers of Mitchell's 1989 excavation (Mitchell 1993) (See Figure 2). All lithic materials from this square were analyzed, with no preferential size sorting within this sample.

To better understand the nature of small tool production at the site, this study focused on the role of freehand and bipolar reduction in the manufacture of the assemblage, and on determining the role size plays in structuring the use of these two methods. It focused on these two methods of reduction because the distinction between them is well-documented (see Pargeter and Duke 2015 and papers therein). This study employed an attribute based approach to distinguish between bipolar and freehand reduction on the cores and flakes. The chosen attributes follow de la Peña \& Vega Toscano (2013); de la Peña (2015b); Flenniken (1981); Knuttson (1988a); Mourre \& Jarre (2011); Jeske \& Lurie (1993), and Pargeter \& de la Peña (submitted) (see Table 3).

\section{TABLE 3: TRAITS DIFFERENTIATING FREEHAND AND BIPOLAR REDUCTION}


The approach to distinguishing between bipolar and freehand reduction differentiates between silicate rock types (e.g. chert) and quartz. Crystalline quartz can be divided into two main categories, vein/milky quartz and crystal quartz (Mourre 1996; de la Peña 2015b). Crystal quartz is homogenous and generally plain- and grain-free and in this respect it responds to bipolar reduction in similar ways to silicate-rich rocks such as obsidian. While exhibiting micro-scale conchoidal fracture, vein quartz is generally anisotropic with frequent internal flaws and coarse grains characterizing its more heterogeneous varieties (Driscoll 2010). These internal structures affect the passage of bipolar forces through quartz, with frequent stepping, fissuring, shearing and splitting of vein quartz cores and flakes (de la Peña 2015b).

This study breaks down distinguishing attributes into those found on cores and flakes because the criteria for identifying bipolar reduction vary between them (Table 3). Ongoing experiments show that flakes exhibit signs of bipolar damage most often in their platform areas (crushed and fissured), bulbs (sheared and hinged), and terminations (splintered and crushed) (Pargeter \& de la Peña Submitted). Bipolar cores are generally flatter, more elongated, and twisted than freehand cores. They also tend to show a degree of crushing around their impact points and in the occasional bi-directional configuration of their flake removal surfaces (de la Peña 2015b). Because no single flake or attribute-type is indicative of bipolar reduction an assemblage-level approach is necessary to identify and quantify the differences between bipolar and freehand reduction. Bipolar reduction can best be identified by examining large samples of flakes and cores and by quantifying sets of relevant categorical and continuous variables on them.

\section{RESULTS}

\section{Cores}

When non-identifiable flake fragments are excluded, cores form $12 \%(n=84)$ of the sample (Table 4). Most cores are 'small' with lengths $<24 \mathrm{~mm}$ and masses $<5 \mathrm{~g}$ (Figure 3). The upper range of length, width, thickness, and mass values for minimally utilized chunks and manuports at the site are high (Table 5, Figure 4). These values suggest that 'large' raw material nodules 
were available to knappers. Chert, agate, and chalcedony manuports are relatively large with maximum length and mass values of $72 \mathrm{~mm}$ and $100 \mathrm{~g}$ respectively (Table 5). While not all of these chunks were used, they demonstrate the raw material size range with which stone tool makers had to work. Crystal quartz manuports, on the other hand, are exceptionally small with length values between $4.89 \mathrm{~mm}$ and $29.67 \mathrm{~mm}$ and mass values between $0.03 \mathrm{~g}$ and $6.98 \mathrm{~g}$. That stone tool makers had access to a range of raw material sizes suggests that the pattern of lithic miniaturization was a conscious one, not a consequence of raw material size or shape.

\section{FIGURE 4: MANUPORTS}

\section{TABLE 5: OVERVIEW OF CORES AND FLAKES DATA}

Bipolar technology was used to reduce the majority (75 \%) of the cores at Ntloana Tšoana (Table 4). The bipolar cores display signs of bi-directional flake scarring, blunting, splintering, and crushing of the striking platforms and torsion around the knapping axis (see examples in Figure 5). The freehand cores display well-formed platforms and unidirectional flake release surfaces without the characteristic bipolar crushing and fissuring on the platforms (see examples in Figure 5).

\section{FIGURE 5: CORES AND BIPOLAR KNAPPING VARIABILITY}

\section{TABLE 5: MORPHOMETRIC DATA FOR PHASE 5 CHUNKS AND MANUPORTS}

Because Ntloana Tšoana is close to abundant sources of fine grained chert, agate, chalcedony and crystalline quartz the high frequencies of bipolar cores are surprising. Tool makers appear not to have used bipolar reduction in response to raw material scarcity, unless access to rock sources or raw material visibility was different during the terminal Pleistocene. Based on current survey evidence it appears that a variety of raw material types occurred at varying elevations and in diverse geological contexts around Ntloana Tšoana (see Figure 3). It is therefore difficult to imagine how changes in river level or soil/vegetation cover, unless in extreme measure, could affect this. Alternative hypotheses for why such high frequencies of bipolar reduction occur at the site could include scheduling arrangements, time-stress, demographic and mobility factors, 
stone tool maker's preference for the method, and the suitability of bipolar technology for overcoming any structural impurities present in these local rocks (sensu Parry \& Kelly 1986; Torrence 1989).

Figure 6 shows the data distributions for the core linear measurements and masses. The bipolar and freehand core distributions show marked differences with respect to location, scale, and shape. They are statistically different in all of the measured indices. The two core populations differ most in their mass, width, and thickness values, with the smallest cores $(<5 \mathrm{~g})$ at Ntloana Tšoana having short, narrow profiles. Although these distributions show patterning in reflecting the difference between freehand and bipolar cores, considerable variability appears in the distribution of the bipolar core mass and thickness values (see Figure 6). These within-group differences suggest considerable variability in bipolar cores that may reflect further variability in bipolar reduction at the site.

\section{FIGURE 6: SIZE DISTRIBUTIONS FOR CORES}

The data distributions in Figures 3 \& 6 show a marked disjunction between the smaller bipolar and larger freehand cores. When reducing small cores, tool makers may switched from freehand to bipolar reduction in a process not unlike the "recycling window" described by Hiscock (2014: 7). Hiscock suggests that bipolar reduction enabled tool makers to surpass size thresholds in core reduction and to continue the reduction of especially small freehand cores. At Ntloana Tšoana the switch between freehand and bipolar reduction occurred when cores reached approximately $25 \mathrm{~mm}$ in length and $3 \mathrm{~g}$ in mass. This transition is similar to the mass values (c. $10-2 \mathrm{~g}$ ) recorded for the switch between bipolar and freehand cores at other southern African Late Pleistocene sites (Mackay et al. 2015: Figure 6). The relationship between freehand and bipolar reduction at Ntloana Tšoana is complex, with many of the site's larger cores ( $>24 \mathrm{~mm}$ length, $>$ $5 \mathrm{~g}$ ) showing signs of bipolar reduction (see Figures 5 \& 9). Approximately $17 \%$ of the bipolar cores retain high amounts of cortex (40 - $90 \%$ ) suggesting the use of bipolar reduction in the earlier stages of core reduction (see Figure 7). Beyond a certain size threshold, knappers appear to have operationalized bipolar and freehand reduction simultaneously, but only bipolar reduction allowed them systematically to reduce the smallest cores. 


\section{FIGURE 7: BIPOLAR CORE CORTEX FREQUENCIES}

\section{Flakes}

The majority of flakes in the Ntloana Tšoana assemblage are non-identifiable fragments (77 \%) (Table 4). Flake fragments comprising proximal, medial and distal portions make up $16 \%$ of the debris and dominate both the bipolar and freehand sub-samples. Complete flakes make up $4 \%$ of the assemblage and are more common in the bipolar sub-sample (26\%) than in the freehand subsample (13\%) (Table 6). Pargeter \& de la Peña (submitted) found similarly high frequencies of complete flakes in their quartz axial bipolar experiments. These data suggest bipolar reduction is not as unreliable a strategy for flake production as is commonly thought.

At Ntloana Tšoana, tool makers used bipolar reduction for a range of technical purposes. Amongst other purposes, they appear to have used bipolar reduction as a core maintenance strategy. Freehand cores with problematic flake release surfaces were turned on their side and a precise bipolar blow delivered across the problematic core surface. The resulting management flakes show diagnostic bipolar attributes (crushed platforms, bipolar, axial or splintered terminations and evidence of rebound force). These attributes often appear perpendicular to dorsal surface freehand reduction scars (see Figure 5). The presence of bipolar split-cobble remnants suggest that bipolar reduction was also used to initiate the knapping of small, round, silicate nodules (see Figure 5). These examples demonstrate the complex inter-weaving of freehand and bipolar reduction at Ntloana Tšoana.

Figure 8 illustrates the distribution of linear measurements for the complete freehand and bipolar flakes with $<40 \%$ dorsal surface cortex (i.e. from later stage reduction; Scerri et al. 2015). A Kmeans cluster analysis on the length and width values for complete flakes shows that the size difference between large and small flakes at Ntloana Tšoana lies at $18 \mathrm{~mm}$ in length and $5 \mathrm{~mm}$ in width (Figure 3). Unlike the core data, the size and mass distributions for freehand and bipolar flakes are indistinguishable (see Figure 8). Tool makers produced morphometrically similar flakes using two different reduction strategies. 


\section{FIGURE 8: SIZE DISTRIBUTIONS FOR FLAKES}

At Ntloana Tšoana, stone tool makers used flakes down the smallest size fraction. Small flakes showing probable signs of utilization are almost four times as common as retouched flakes (1\% vs $0.32 \%$ ), with both of these types making up a minor portion of the bipolar and freehand flake assemblage (4.15\% and $5.84 \%$ respectively) (Table 6, Figure 9). The similar frequencies of utilized and retouched flakes in both bipolar and freehand components show that tool makers considered both of these flake sub-samples as viable sources of usable material (Table 6). These damage patterns consist of random edge micro-fractures and crushing. Impact fractures likely associated with weapon functions also appear on the small flakes and bladelets (see Figure 9). These small unretouched flakes and bladelets show signs of possible macro-residues (see Figure 9).

\section{FIGURE 9: UTILIZED FLAKES}

\section{TABLE 6: FLAKE DETAILS}

\section{Raw material variability}

Most (75\%) of the smallest cores at Ntloana Tšoana were made on quartz crystals (Table 7). These crystal quartz cores have average length $(9.11 \mathrm{~mm})$, width $(5.35 \mathrm{~mm})$, thickness $(3.24$ $\mathrm{mm})$, and mass $(0.24 \mathrm{~g})$ values distinctively smaller than the non-quartz cores in the assemblage (Table 9; see Figure 10). The largest crystal quartz cores are between $1.5-0.22 \mathrm{~g}$ in mass and $21.89-0.89 \mathrm{~mm}$ in length. They are generally unstandardized with Coefficient of Variation values between 30 and 121 (Table 9).

The small crystal quartz cores occur in two primary shapes, flat and thin and narrow and pointed (see Figure 10). Narrow and pointed cores are commonly referred to as 'rice-grain cores' due to their short, elongate and cylindrical morphologies (Davis 1980) (see Figure 10). Flat and thin bipolar cores are commonly referred to as 'flat bladelet cores' in reference to their thin morphology and the presence of elongate flake scars on their surfaces (Deacon, J. 1984) (see Figure 10). Chert dominates the larger core (> $24 \mathrm{~mm}$ length) fraction (60\%), but it drops off in the smaller fraction (18\%) as does chalcedony (19\% vs. $6 \%$ ). Agate and hornfels each form a 
numerically small component of the larger core sample and were not used to produce the smallest cores at Ntloana Tšoana. Tool makers used freehand reduction to reduce cores on both of these raw materials.

\section{TABLE 7: RAW MATERIAL BREAKDOWN: CORES}

\section{TABLE 8: RAW MATERIAL BREAKDOWN: FLAKES}

Chert is the most common rock type in the small and large flakes category. Chalcedony, crystal quartz, and quartzite follow in declining frequency (Table 8). Lithic production took place across a range of rock types, but knappers preferred fine grained and homogenous rocks. Crystal quartz flakes are rare despite their dominance in the small-core group. This can be explained by their use offsite or by intra-site spatial variations, an hypothesis that will be tested by future analyses.

\section{TABLE 9: CRYSTAL QUARTZ CORE METRICS}

\section{DISCUSSION}

\section{Could the crystal quartz cores have been the accidental by-products of quartz knapping?}

Quartz tends to break along natural fissures and flaws. These breakage patterns can be difficult to distinguish from intentional human modification. To account for these processes of equifinality, this study employed strict criteria to identify the small crystal quartz cores. These criteria incorporate those identifications from previous work by Knutsson (1988b) Diez-Martín and colleagues (2011), and de la Peña (2015b). Three criteria eliminating flake debris, wedges and broken cores in the crystal quartz core sample:

1. They must have an area where they were hammered upon and an area where they were rested upon the anvil (i.e. an area where force initiates opposed by an area where force terminates and/or rebounds). 
2. They must have a series of clear and complete flake removals extending mid-way across the core face to eliminate intermediate pieces (wedges).

3. They must have between 270 and 360 degrees of flake removals around their circumference to eliminate flakes or split cores.

The nearest source for crystal quartz is c. 4 km away from Ntloana Tšoana (see Figure 1). Given that it occurs only within the local basalt it is not a rock type occurring naturally within the shelter (Cairncross 2004). Tool makers chose to procure quartz crystals and then to systematically reduce them to such small sizes. This decision making process is striking given the abundance of fine grained silicate rocks within a $1 \mathrm{~km}$ radius of Ntloana Tšoana (see Figure 1). One explanation for this pattern could be that quartz crystals provide knappers with a natural prismatic structure for elongated flake production. Prismatic structures contribute to the success of blade and bladelet technologies especially those on narrow, cylindrical cores (Inizan et al. 1999). These prismatic cores are difficult to prepare and the techniques can take considerable skill and time to master (Shea 2015). Quartz crystals would have provided knappers with a naturally occurring prismatic structure without the need to prepare one. In this sense knappers appear to have enacted a process of 'biomimicry' by exploiting a naturally occurring geological structure for purposes originating in a human technological system.

This evidence for small bipolar elongated flake or bladelet production contradicts claims that the method "is too coarse and uncontrollable for manufacturing regular standard products such as microblades with parallel sides and parallel dorsal ridges" (Ballin 1999: 18). Archaeologists have made similar observations about the usefulness of bipolar reduction for systematic blade and bladelet production at the nearby Rose Cottage Cave site and in the MSA layers at Ntloana Tšoana (A. M. B. Clark 1999; Lewis 2015). These observations echo Brantingham and colleagues (2004) in Northern China, who argue systematic bladelet production using freehand, pressure and punch techniques evolved out of a bipolar substrate.

FIGURE 10: FLAT AND PPOINTED CRYSTAL QUARTZ BIPOLAR CORES

\section{How were the crystal quartz cores and flakes made and used?}


All the crystal quartz cores were produced using a bipolar technique. Their frequently crushed platforms and distal ends as well as the bidirectional flake scars on the quartz crystal core surfaces support this interpretation (Figure 10). Their use as wedges can be ruled out by the fact that all of them have flake scars extending over halfway on the core face signaling an intention towards flake production (also see Shott 1989). Moreover, the morphology of these cores does not match the wedge shape that is central to the definition of these intermediate pieces (Hayden 1980). The crystal quartz cores show no prior signs of freehand knapping suggesting either that their reduction began with a bipolar technique, or that these prior knapping scars have been obliterated. The crystal quartz manuports found at Ntloana Tšoana are small (Figure 4). They range in length between 4.89 and $29.67 \mathrm{~mm}$ and in mass between 0.03 and $6.98 \mathrm{~g}$. When one compares these values to the crystal quartz bipolar core metrics, it is clear that knappers did not simply discard these crystals because they were too small. Crystal quartz cores were small to begin with and that during bipolar reduction they lost on average $50 \%$ of their volume.

It is not possible at present to be certain for what purposes these small flakes were used. Clear signs of damage appear on the crystal quartz and other small flakes in the Ntloana Tšoana assemblage (Figure 9). Some of the crystal quartz flakes have diagnostic impact fractures indicative of weapon related impacts, while others show minor edge deformation (see for example Pargeter 2013; also see Figure 9). These preliminary lines of evidence suggest a range of tasks for the small crystal quartz flakes and bladelets, including as miniaturized components in hunting weapons (also see Binneman 1997; Binneman and Mitchell 1997). The development of the bow and arrow in southern Africa was intimately linked to the spread of miniaturized lithic technologies (e.g. small backed tools) (e.g. Pargeter et al. 2016; Brown et al. 2012; Lombard and Phillipson 2010). Might this spread be linked to lithic miniaturization in general?

\section{Can the crystal quartz bipolar cores be explained by raw material stress?}

Raw material stress is often used to explain the occurrence of bipolar technology, especially on quartz (for a discussion see Gurtov and Eren 2014). Hydrothermal vein quartz is a challenging material to knap and bipolar reduction allows knappers to reduce it beyond the size thresholds of 
freehand reduction. Crystal quartz, in contrast, is structurally homogenous and posses fewer challenges. One might therefore expect increased frequencies of bipolar reduction in contexts where quartz is ubiquitous, or where quartz is a raw material of last resort and where reducing a core to its smallest size is compulsory (e.g. Eren et al. 2012). Such situations include those in which access to alternative sources of rock is restricted through social factors, or where alternative rock supplies are exhausted. The available survey raw material data from Ntloana Tšoana suggest that the site was located in a rich and diverse raw material environment (see Tables 8 \& 9). That the Ntloana Tšoana lithic assemblage contains large chunks and manuports (c. $100 \mathrm{~g}$ ) demonstrates that knappers had options when choosing which sized rocks to knap, and when to abandon them (see Figure 4, Table 5). In such a context, knappers clearly chose to reduce quartz crystals to such small sizes for reasons unrelated to stresses over rock availability.

\section{How do these small crystal quartz cores compare to small cores elsewhere?}

The small size of the crystal quartz cores at Ntloana Tšoana begs the question of how small is small in 'microlithic' assemblages? For Shea (2006) small begins at around 20 - $30 \mathrm{~mm}$ in length. Archetypal 'micro'-blade cores from Siberia and Alaska are on average between 30 and $50 \mathrm{~mm}$ in length, which is at least three times larger than the crystal quartz cores at Ntloana Tšoana (Brantingham et al. 2001; Goebel 2002; Yesner and Pearson 2002; Nakazawa et al. 2005). Exhausted flint bladelet cores from the Iberomaurusian in North Africa are around $30 \mathrm{~mm}$ in length (Close 2002). Proto-Aurignacian bladelet cores are on average around $30 \mathrm{~mm}$ in maximum length (Kuhn 2002). Similar sizes are reported for small quartz cores dating to c. $18 \mathrm{ka}$ found in the Ituri Forests of Central Africa (Mercader and Brooks 2001). The Ntloana Tšoana cores and debris are considerably smaller than these.

Lithic illustrations from the sites of Byneskranskop 1, Boomplaas, Nelson Bay Cave, and Elands Bay Cave in the Western Cape province of South Africa show cores that are similarly sized (c. $10 \mathrm{~mm}$ length) to those at Ntloana Tšoana (Davis 1980; Schweitzer and Wilson 1982; J. Deacon 1984). These deposits are similar in age to those at Ntloana Tšoana, with the relevant deposits at Elands Bay Cave (Layer 18) dating to 13 - $11 \mathrm{ka}$ calBP, and at Boomplaas (unit CL) to 13 - 12 ka calBP (Davis 1980; J. Deacon 1984). At this point we need to consider the possibility that 
increased lithic miniaturization and bipolar reduction may be linked to resource intensification and increasing population densities as are assumed to have characterized the Late and terminal Pleistocene in southern Africa (Ambrose and Lorenz 1990; Ambrose 1998b).

At Byneskranskop 1 (layer 19) and Nelson Bay Cave (unit YSL) dates of $17-16 \mathrm{ka}$ calBP and $18-17$ ka calBP respectively place similar small crystal quartz cores at the end of the Last Glacial Maximum (LGM) (c. $22.3 \pm 3.6$ ka BP) (J. Deacon 1982: 97; P. U. Clark et al. 2009; Loftus et al. 2016). These ages hint at possible correlations between reductions in core size, resource intensification and climatic degradation associated with the LGM. Yet, the persistence of so-called Robberg toolkits on either side of the LGM in southern Africa would caution against any simple correlation here.

At Sehonghong in the Lesotho Highlands, small cores $<1 \mathrm{~cm}$ in length occur in layers dated to $\mathrm{c}$. $30 \mathrm{ka}$ calBP, while at Putslaagte 8 , cores $<1 \mathrm{~g}$ in mass are in used at $40 \mathrm{ka}$ BP (Mackay et al. 2015; Pargeter and Redondo 2015). Older examples of systematic small core reduction on quartz using bipolar reduction are reported from the Grey Sand layers at Sibudu Cave (de la Peña and Wadley 2014). These bipolar cores weigh on average around $0.8 \mathrm{~g}$ with a mean length of $15 \mathrm{~mm}$. These dimensions are similar to the Ntloana Tšoana crystal quartz cores. Bipolar cores of agate and chalcedony weighing $<1 \mathrm{~g}$ appear in the Howieson's Poort deposits at Ntloana Tšoana (Lewis 2015).

Exhausted quartz bipolar cores found in western Arnhem Land, Australia, weigh between $3 \mathrm{~g}$ and $5 \mathrm{~g}$ (Hiscock 2015b), with lower values of c. $1 \mathrm{~g}$ reported for the silcrete and chert cores from the Henry Lawson Drive site in Sydney (Hiscock 2015a). Data for the chert and silcrete bipolar cores from the Late Pleistocene deposits at Klein Kliphuis and Putslaagte 8 in South Africa fall in the same mass range (c. $1 \mathrm{~g}$ ), but quartz cores often extend down in size to $0.1 \mathrm{~g}$ (Mackay et al. 2015). Callahan (1987) notes similarly sized quartz bipolar cores in the Swedish Mesolithic. These mass data suggest that a technological pattern of exceptionally small core reduction facilitated by bipolar reduction was widespread during the Late Pleistocene and Holocene in southern Africa, Australia and Europe. 
These data suggest that the pattern of bipolar reduction linked to systematic lithic miniaturization involving small unretouched toolkits seen at Ntloana Tšoana is not an isolated phenomenon. Rather, this pattern may may be evolutionarily ancient in southern Africa and elsewhere. That the unretouched miniaturized component of the Ntloana Tšoana lithic assemblage went unnoticed during the 1989 excavations at the site suggest that many other similar assemblages may await discovery at other sites in southern African and elsewhere. Their proliferation may have involved complex decision making processes involving a wide range of social factors, demographic processes, time and resource management, and possibly the large scale effects of climate change. What we need to know is how technologically superficial these similarities are when compared between sites across time and space in Africa and with regions outside of southern Africa.

\section{Where else might the systematic production of small unretouched toolkits occur?}

Everywhere. The systematic recycling of larger flakes to produce small flakes is documented at Bizat Ruhama, Israel (1.6 - 1.2 mya) (Zaidner, 2013). At the c. 400 ka site of Revadim in Israel, hominids systematically produced small $(<20-30 \mathrm{~mm})$ unretouched flakes by way of larger flake recycling (also see Goren-Inbar 1988; Shea and Bar-Yosef 1999; Agam et al. 2014). Microwear analyses show that these small flakes were used to cut vegetal materials (Lemorini et al. 2015). Small flakes, c. $10-30 \mathrm{~mm}$ long, with microwear traces of butchery appear in Qesem Cave in Israel dating to $400-200 \mathrm{ka}$ (Barkai, et al., 2010).

Shea (2008) notes systematic small tool production using small ( $<40 \mathrm{~mm}$ ) Levallois cores in the mid-Pleistocene deposits at Omo Kibish in Ethiopia. The Middle Paleolithic site of Pech de l'Azé IV in France contains evidence for the systematic reduction of small $(<30 \mathrm{~mm})$ Levallois

and Kombewa cores to produce small flakes with mean maximum dimensions ranging from 19.6 to $25 \mathrm{~mm}$ (Bordes 1975; also see Moncel 2003; Dibble and McPherron 2006). The Upper Paleolithic Gravettian site of El Palomar in the southeastern Iberian Peninsula contains abundant evidence for the production and use of small flakes and bladelets using a bipolar technique (de la Peña \& Vega Toscano 2013). At Katanda, in the Democratic Republic of Congo, a single unretouched quartz flake was found inserted into an engraved bone handle dating $90-60 \mathrm{ka}$ 
(Yellen et al. 1995). This small unretouched quartz flake was unequivocally used as a hafted implement.

Ethnographic observations document numerous examples of humans using small unretouched toolkits. The Duna-speaking people of the Central Highlands region of Papua New Guinea use bipolar reduction to produce small stone slivers measuring between $20-30 \mathrm{~mm}$ in length (White and Thomas, 1972). These tools are used in hand without any form of hafting (Watson, 1995). The Aboriginal populations in Victoria, Australia, have at least six categories of small unretouched flakes and chips in their stone toolkits (Smyth, 1878). These small flakes served multiple purposes including as cutting, skinning, chiseling, and scarification implements and are frequently hafted as chips in barbed spears. Historical documents show that these so-called 'death spears', armed with multiple unretouched chips of quartz, were in use across Australasia (Flood, 1995). The Konso hide-workers of southeastern Ethiopia make and curate small retouched scrapers for use in hide-working implements. The blanks for these tools are produced using bipolar and begin at between $20-40 \mathrm{~mm}$ (Shott and Weedman, 2007). Numerous other ethnographic examples show that humans made, used and valued unretouched miniaturized tools (Stow, 1905, Hayden and Nelson, 1981, Hayden, 1979, Deal and Hayden, 1987).

\section{CONCLUSIONS}

The term 'microlith' has grown to include a range of technologies and tool types not included in the original definition intended to identify and describe small retouched tools. This is a natural outcome of the expansion in global research on the broader and more inclusive topic of lithic miniaturization. Small unretouched toolkits were used widely in prehistory and are a common occurrence in ethnographic contexts. The archaeological example presented from Ntloana Tšoana demonstrates what such an assemblage looks like. The following are key characteristics:

1. These assemblage feature low retouched tools (c. 0 - $1 \%$ ).

2. There is evidence for the use of unretouched flakes.

3. They contain evidence for the systematic production of small flakes/bladelets from small cores. 
4. The reduction of small cores is a choice made within the context of larger raw material options.

5. They can be made on a range of rock types.

6. They can be made using a range of lithic reduction strategies.

Combining existing technological terminology, qualitative and statistical methods, we have an accurate, replicable and contextual method for identifying and describing the presence of 'small' unretouched tools and cores in lithic assemblages. The examples presented by Pargeter \& Redondo (2015) demonstrate these methods for detecting and quantifying the presence of small unretouched bladelets. The same principles using standard metrics of length, width and thickness can help detect size-clustering in flake-based assemblages. These size clusters can then be assessed for internal coherence and technological validity using other technologically relevant attributes. Collectively, these techniques form a contextual approach to studying small tool production, one that employ standardized quantitative and qualitative methods to derive site specific size and morphological descriptions of miniaturized toolkits (see Lewis 2015 for an example).

Lithic miniaturization provided humans with a flexible suite of technological solutions well adapted to resource intensification, shifting mobility strategies, functional flexibility and ecological variability. That we find numerous examples of small toolkits in various parts of Northeast Asia, Africa, and as humans awaited entry in the Americas support this idea. Small, multifunctional, unretouched toolkits were parts of our ancestral toolkits beyond 1 mya and were still in use by ethnographically documented populations in the 1970s. This technological flexibility derives from a range of techniques with which to produce small tools from small cores. Although important for understanding human behavioral variability, these patterns of small tool production and use extend beyond that encompassed within the 'microlith' concept. Archaeologists may be better positioned to study variability within lithic miniaturization processes by separating these two behavioral processes (small tool production and small tool retouch) in archaeological assemblages. By doing so we can compare instances of both production strategies and to more accurately understand their respective roles in broader patterns of lithic miniaturization and its implications for human behavioral evolution. 


\section{ACKNOWLEDGEMENTS}

I would to thank two anonymous reviewers and the editor for their insights into an earlier draft of the paper. Charles Arthur and the Department of Culture of the Government of Lesotho deserve special thanks for providing access to the Ntloana Tšoana lithic collection. A further thank you to Charles Arthur for providing site section and plan drawings as well as the geological survey maps in advance of their publication. Special thanks are due to John Shea, Paloma de la Peña, Peter Mitchell, Charles Arthur, William Mills, and Alex Mackay for extensive feedback on the paper. Funding for this work was provided by the National Science Foundation Doctoral Dissertation Improvement Grant (award ID: 112660172177), the Dan David Prize and the Leakey Foundation Mosher Baldwin Fellowship.

\section{REFERENCES}

Abbott, W.J.L., (1913). Pygmy Implements from Cape Colony, Man 13, 143-147.

Agam, A., Marder, O., \& Barkai, R. (2014). Small flake production and lithic recycling at Late Acheulian Revadim, Israel. Quaternary International 361, 46-60.

Ambrose, S. H. (1998a). Chronology of the later Stone Age and Food Production in East Africa. Journal of Archaeological Science 25, 377-392.

Ambrose, S. H. (1998b). Late Pleistocene human population bottlenecks, volcanic winter, and the differentiation of modern humans. Journal of Human Evolution 34, 623-651.

Ambrose, S. H. (2002). Small things remembered: Origins of early microlithic industries in subSaharan Africa. In R. G. Elston, \& S. L. Kuhn (Eds.), Thinking Small: Global Perspectives on Microlithization (pp. 9-30). Washington: American Anthropological Association.

Ambrose, S. H., \& Lorenz, K. G. (1990). Social and ecological models for the Middle Stone Age in southern Africa. In P. T. Mellars (Ed.), The Human Revolution: Behavioral and Biological Perspectives in the Origins of Modern Humans (pp. 3-33). Edinburgh: Edinburgh University Press.

Amick, D.S., 2007. Investigating the behavioral causes and archaeological effects of lithic recycling, in: McPherron, S. (Ed.), Tools versus cores: alternative approaches to stone tool analysis, Cambridge Scholars Publishing, Cambridge, pp. 223-252.

Arthur, C., \& Mitchell, P. J. (2012). Metolong Cultural Resource Management Phase 4, Final Report. Unpublished report prepared for the Lesotho Government's Commissioner for Water. University of Oxford: School of Archaeology.

Ballin, T. B. (1999). Bipolar cores in southern Norway: classification, chronology and geography. Lithics 20, 13-22.

Bamforth, D. B., \& Bleed, P. (1997). Technology, Flaked Stone Technology, and Risk. In C. M. Barton, \& G. A. Clark (Eds.), Rediscovering Darwin: Evolutionary Theory and 
Archeological Explanation (pp. 109-139). Washington: American Anthropological Association.

Bar-Yosef, O., \& Kuhn, S. L. (1999). The big deal about blades: Laminar technologies and human evolution. American Anthropologist 101, 322-338.

Barham, L. (2013). From Hand to Handle: The First Industrial Revolution: Oxford University Press.

Barkai, R., Lemorini, C., Gopher, A., 2010. Palaeolithic cutlery 400 000-200 000 years ago: tiny meat-cutting tools from Qesem Cave, Israel, Antiquity 84.

Basak, B., Srivastava, P., Dasgupta, S., Kumar, A., \& Rajaguru, S. (2014). Earliest dates and implications of Microlithic industries of Late Pleistocene from Mahadebbera and Kana, Purulia district, West Bengal. Current Science (00113891), 107.

Belfer-Cohen, A., \& Goring-Morris, N. (2002). Why Microliths? Microlithization in the Levant. In R. G. Elston, \& S. L. Kuhn (Eds.), Thinking Small: Global Perspectives on Microlithization (pp. 57-68). Washington, DC: American Anthropological Association.

Bettinger, R. L., Morgan, C., \& Barton, L. (2015). The North China Nanolithic. In N. Goodale, \& W. Andrefsky (Eds.), Lithic Technological Systems and Evolutionary Theory (pp. 100). Cambridge: Cambridge University Press.

Binneman, J. (1997). Usewear traces on Robberg bladelets from Rose Cottage Cave. South African Journal of Science 93, 479-481.

Binneman, J., \& Mitchell, P. J. (1997). Usewear analysis of Robberg bladelets from Sehonghong Shelter, Lesotho. Southern African Field Archaeology 6, 42-49.

Bleed, P. (2002). Cheap, regular, and reliable: Implications of design variation in Late Pleistocene Japanese microblade technology. In R. G. Elston, \& S. L. Kuhn (Eds.), Thinking Small: Global Perspectives on Microlithization (pp. 95-102). Washington, DC: American Anthropological Association.

Bordes, F. (1975). Le gisement de Pech de l'Aze' IV: Note pre'liminaire. Bulletin de la Socie'te' Pre'historique Francaise 72, 293-308.

Brantingham, P. J., Gao, X., Madsen, D. B., Bettinger, R. L., \& Elston, R. G. (2004). The initial upper Paleolithic at Shuidonggou, Northwestern China. In P. J. Brantingham, S. L. Kuhn, \& K. W. Kerry (Eds.), The Early Upper Paleolithic Beyond Western Europe (Vol. Berkeley, pp. 223-241): University of California Press.

Brantingham, P. J., Krivoshapkin, A. J., Jinzheng, L., \& Tserendagva, Y. (2001). The Initial Upper Paleolithic of Northeast Asia. Current Anthropology 42, 735-747.

Burdukiewicz, J., (2005). Microlithic technology in the Stone Age, Journal of the Israeli Prehistoric Society 35, 337-351.

Burdukiewicz, J. M., \& Ronen, A. (Eds.). (2003). Lower Paleolithic Small Tools in Europe and the Levant, , BAR International Series. Oxford: Archeopress.

Cairncross, B. (2004). Field guide to rocks \& minerals of Southern Africa. Johannesburg: Struik.

Callahan, E. (1987). An evaluation of the lithic technology in Middle Sweden during the Mesolithic and Neolithic: Societas Archaeologica Upsaliensis.

Cattell, R. B., \& Vogelmann, S. (1977). A comprehensive trial of the scree and KG criteria for determining the number of factors. Multivariate Behavioral Research 12, 289-325.

Clark, A. M. B. (1999). A Technological And Behavioural Interpretation Of The Change From The Middle Stone Age To The Later Stone Age In South Africa. Unpublished PhD dissertation, University of the Witwatersrand, Johannebsurg.

Clark, G. (1969). World Prehistory: A New Synthesis. Cambridge: Cambridge University Press. 
Clark, J. D. (1985). The microlithic industries of Africa: their antiquity and possible economic implications. In Recent Advances in Indo-Pacific Prehistory: Proceedings of the International Symposium Held at Poona, December 19-21, 1978, (pp. 95-103): Oxford \& IBH Pub. Co. New Delhi

Clark, P. U., Dyke, A. S., Shakun, J. D., Carlson, A. E., Clark, J., Wohlfarth, B., et al. (2009). The Last Glacial Maximum. Science 325, 710.

Clarkson, C., Petraglia, M., Korisettar, R., Haslam, M., Boivin, N., Crowther, A., et al. (2009). The oldest and longest enduring microlithic sequence in India: 35000 years of modern human occupation and change at the Jwalapuram Locality 9 rockshelter. Antiquity 83, 326-348.

Close, A. E. (2002). Backed bladelets are a foreign country. In R. G. Elston, \& S. L. Kuhn (Eds.), Thinking Small: Global Perspectives on Microlithization (pp. 31-44). Washington: American Anthropological Association.

Davis, M. F. (1980). Some aspects of Elands Bay Cave stone artefacts. University of Cape Town, Cape Town.

de la Peña, P., \& Vega Toscano, G. (2013). Bipolar knapping in Gravettian occupations of El Palomar rockshelter (Yeste, South Eastern Spain). Journal Of Anthropological Research 69, 33-64.

de la Peña, P. (2015a). The interpretation of bipolar knapping in African Stone Age studies. Current Anthropology 56, 911-923.

de la Peña, P. (2015b). A qualitative guide to recognize bipolar knapping for flint and quartz. Lithic Technology 4, 1-16.

de la Peña, P., \& Wadley, L. (2014). New knapping methods in the Howiesons Poort at Sibudu (KwaZulu-Natal, South Africa). Quaternary International 350, 26-42.

Deacon, H. J., \& Deacon, J. (1999). Human Beginnings in South Africa: Uncovering the Secrets of the Stone Age. Walnut Creek: Altamira Press.

Deacon, J. (1982). The later Stone Age in the Southern Cape, South Africa. Unpublished PhD Thesis. University of Cape Town, Cape Town.

Deacon, J. (1984). The Later Stone Age of Southernmost Africa. BAR International Series. Oxford: Archaeopress.

Desrosiers, P. M. (Ed.). (2012). The Emergence of Pressure Blade Making: From Origin to Modern Experimentation. New York: Springer.

Dibble, H. L., \& McPherron, S. P. (2006). The missing Mousterian. Current Anthropology 47, 777-803.

Diez-Martín, F., Yustos, P., Domínguez-Rodrigo, M., \& Prendergast, M. (2011). An experimental study of bipolar and freehand knapping of Naibor Soit quartz from Olduvai Gorge (Tanzania). American Antiquity 76, 690-708.

Driscoll, K. (2010). Understanding quartz technology in early prehistoric Ireland. $\mathrm{PhD}$, University College Dublin, Dublin.

Driscoll, K. (2015). The role of quartz in Neolithic lithic traditions: a case study from the Thornhill Early Neolithic palisaded enclosure, Co. Derry Londonderry, Northern Ireland. Proceedings of the Royal Irish Academy. Section C: Archaeology, Celtic Studies, History, Linguistics, Literature, 1-27.

Elston, R. G., \& Brantingham, P. J. (2002). Microlithic technology in Northern Asia: A riskminimizing strategy of the Late Paleolithic and Early Holocene. In R. G. Elston, \& S. L. 
Kuhn (Eds.), Thinking Small: Global Perspectives on Microlithization (pp. 103-116). Washington, DC: American Anthropological Association.

Elston, R. G., \& Kuhn, S. L. (Eds.). (2002). Thinking Small: Global Perspectives on Microlithization. Washington, DC: American Anthropological Association.

Eren, M. I., Diez-Martin, F., \& Dominguez-Rodrigo, M. (2012). An empirical test of the relative frequency of bipolar reduction in beds VI, V, and III at Mumba Rockshelter, Tanzania: Implications for the East African Middle to Late Stone Age transition. Journal of Archaeological Science 40, 248-256.

Flenniken, J. J. (1981). Replicative systems analysis: A model applied to the vein quartz artifacts from the Hoko River site. Washington State University Laboratory of Anthropology.

Gallotti, R., \& Mussi, M. (2015). The Unknown Oldowan: 1.7-Million-Year-Old Standardized Obsidian Small Tools from Garba IV, Melka Kunture, Ethiopia. PLoS ONE 10, e0145101.

Gilabert, X. R., Mora, R., \& Martínez-Moreno, J. (2015). Identifying bipolar knapping in the Mesolithic site of Font del Ros (northeast Iberia). Philosophical Transactions of the Royal Society B 370, 20140354.

Goebel, T. (2002). The "Microblade Adaptation" and recolonization of Siberia during the Late Upper Pleistocene. In R. G. Elston, \& S. L. Kuhn (Eds.), Thinking Small: Global Perspectives on Microlithization (pp. 117-132). Washington, DC: American Anthropological Association (Archaeological Paper No. 12).

Goren-Inbar, N. (1988). Too small to be true? Re-evaluation of cores on flakes in Levantine Mousterian assemblages. Lithic Technology 17, 37-44.

Gurtov, A. N., \& Eren, M. I. (2014). Lower Paleolithic bipolar reduction and hominin selection of quartz at Olduvai Gorge, Tanzania: What's the connection? Quaternary International $322,285-291$.

Hayden, B. (1980). Confusion in the bipolar world: Bashed pebbles and splintered pieces. Lithic Technology 9, 2-7.

Hiscock, P. (1994). Technological responses to risk in Holocene Australia. Journal of World Prehistory 8, 267-292.

Hiscock, P. (2002). Pattern and Context in the Holocene Proliferation of Backed Artifacts in Australia. In R. G. Elston, \& S. L. Kuhn (Eds.), Thinking Small: Global Perspectives on Microlithization (pp. 163-178). Washington, DC: American Anthropological Association (Archaeological Paper No. 12).

Hiscock, P. (2015a). Dynamics of knapping with bipolar techniques: Modeling transitions and the implications of variability. In J. Pargeter, \& H. Duke (Eds.), Exploring Variability in Bipolar Technology Special Publication of the journal Lithic Technology: 342-349.

Hiscock, P. (2015b). Making it small in the Palaeolithic: Bipolar stone-working, miniature artefacts and models of core recycling. World Archaeology 47, 158-169.

Hiscock, P., Clarkson, C., \& Mackay, A. (2011). Big debates over little tools: Ongoing disputes over microliths on three continents. World Archaeology 43, 653-664.

Honeywood, T., 1877. Discovery of flint implements near Horsham, St Leonard's Forest. Sussex Archaeological Collections 27, 176-183.

Inizan, M.-L., Reduron-Ballinger, M., Roche, H., \& Tixier, J. (1999). Technology and Terminology of Knapped Stone (translated by J. Féblot-Augustins) (Préhistoire de la Pierre Taillée, Tome 5). Meudon, FR: Cercle de Recherches et d'Etudes Préhistoriques (CNRS). 
Jacobs, Z., Roberts, R., Galbraith, R., Deacon, H., Grun, R., Mackay, A., et al. (2008). Ages for the Middle Stone Age of southern Africa: Implications for human behavior and dispersal. Science 322, 733.

Jeske, R. J., \& Lurie, R. (1993). The archaeological visibility of bipolar technology: an example from the Koster site. Midcontinental Journal Of Archaeology, 131-160.

Kanyongo, G. Y. (2005). Determining the correct number of components to extract from a principal components analysis: A Monte Carlo study of the accuracy of the scree plot. Journal of Modern Applied Statistical Methods 4, 13.

Kaufman, D. (1986). A proposed method for distinguishing between blades and bladelets. Lithic Technology 15, 34-40.

Kaufman, L., \& Rousseeuw, P. J. (2009). Finding Groups in Data: An Introduction to Cluster Analysis (Vol. 344). London: John Wiley \& Sons.

Knutsson, K. (1988a). Making and using stone tools: the analysis of the lithic assemblages from Middle Neolithic sites with flint in Västerbotten, northern Sweden (Vol. 11): Uppsala Universitet/Acta Universitatis Uppsaliensis.

Knutsson, K. (1988b). Patterns of Tool Use: Scanning Electron Microscopy of Experimental Quartz Tools. Societas Archaeologica Upsaliensis: Uppsala.

Kuhn, S. L. (2002). Pioneers of Microlithization: The "Proto-Aurignacian" of Southern Europe. In R. G. Elston, \& S. L. Kuhn (Eds.), Thinking Small: Global Perspectives on Microlithization (pp. 83-94). Washington, DC: American Anthropological Association.

Kuhn, S. L., \& Elston, R. G. (2002). Introduction: Thinking small globally. In R. G. Elston, \& S. L. Kuhn (Eds.), Thinking Small: Global Perspectives on Microlithization (pp. 1-8). Washington, DC: American Anthropological Association.

Leakey, L.S.B., 1931. The Stone Age Cultures of Kenya Colony, Cambridge University Press, Cambridge.

Lemorini, C., Venditti, F., Assaf, E., Parush, Y., Barkai, R., \& Gopher, A. (2015). The function of recycled lithic items at late Lower Paleolithic Qesem Cave, Israel: An overview of the use-wear data. Quaternary International 361: 103-112.

Lewis, L. (2015). Early microlithic technologies and behavioral variability in southern Africa and South Asia. Unpublished PhD Thesis. University of Oxford, Oxford.

Loftus, E., Sealy, J., Lee-Thorp, J., 2016. New Radiocarbon Dates and Bayesian Models for Nelson Bay Cave and Byneskranskop 1: Implications for the South African Later Stone Age Sequence, Radiocarbon 58, 365-381.

Lombard, M., Phillipson, L., 2010. Indications of bow and stone-tipped arrow use 64000 years ago in KwaZulu-Natal, South Africa, Antiquity 84, 635-648.

Lombard, M., \& Haidle, M. N. (2012). Thinking a bow-and-arrow set: Cognitive implications of Middle Stone Age bow and stone-tipped arrow technology. Cambridge Archaeological Journal 22, 237-264.

Lombard, M., Wadley, L., Deacon, J., Wurz, S., Parsons, I., Mohapi, M., et al. (2012). South African and Lesotho Stone Age sequence updates (I). South African Archaeological Bulletin 67, 123-140.

Mackay, A., Jacobs, Z., Steele, T. E., \& Orton, J. (2015). Pleistocene Archaeology and Chronology of Putslaagte 8 (PL8) Rockshelter, Western Cape, South Africa. Journal of African Archaeology Vol 13, 1.

Madsen, D. B. (2004). Entering America: Northeast Asia and Beringia Before the Last Glacial Maximum: University of Utah Press. 
McBrearty, S., \& Brooks, A. S. (2000). The revolution that wasn't: A new interpretation of the origin of modern human behavior. Journal of Human Evolution 39, 453-563.

McDonald, J. J., Donlon, D., Field, J., Fullagar, R. L. K., Coltrain, J. B., Mitchell, P., et al. (2007). The first archaeological evidence for death by spearing in Australia. Antiquity 81, $877-885$.

Mellars, P. (2006). Why did modern human populations disperse from Africa ca. 60,000 years ago? A new model. Proceedings of the National Academy of Sciences 103, 9381-9386.

Mercader, J., \& Brooks, A. S. (2001). Across forests and savannas: Later stone age assemblages from Ituri and Semliki, Democratic Republic of Congo. Journal of Anthropological Research, 197-217.

Mishra, S., Chauhan, N., \& Singhvi, A. K. (2013). Continuity of microblade technology in the Indian subcontinent since $45 \mathrm{ka}$ : implications for the dispersal of modern humans. PLoS ONE 8, e69280.

Mitchell, P. J. (1988). The Early Microlithic Assemblages of Southern Africa, BAR International Series (Vol. 388, Vol. 388). Oxford: Archaeopress.

Mitchell, P. J. (1990). A paleoecological model for archaeological site distribution in southern Africa during the Upper Pleniglacial and Late Glacial. In C. Gamble, \& O. Soffer (Eds.), The World at 18000 BP: Volume 2 Low Latitudes (pp. 189-205). London: Unwin Hyman.

Mitchell, P. J. Archaeological Investigations at two Lesotho Rock-shelters: Terminal Pleistocene/Early Holocene Assemblages from Ha Makotoko and Ntloana Tsoana. In Proceedings of the Prehistoric Society, 1993 (Vol. 59, pp. 39-60): Cambridge University Press.

Mitchell, P. J. (1994). Understanding the MSA/LSA transition: The pre-20 000 BP assemblages from new excavations at Sehonghong Rock Shelter, Lesotho. Southern African Field Archaeology 3, 15-25.

Mitchell, P. J. (1995). Revisiting the Robberg: New results and a revision of old ideas at Sehonghong rock shelter, Lesotho. The South African Archaeological Bulletin 50, 28-38.

Mitchell, P. J. (2002). The Archaeology of Southern Africa (Cambridge world archaeology). Cambridge: Cambridge University Press.

Mitchell, P. J., \& Arthur, C. (2010). Archaeological fieldwork in the Metolong Dam catchment, Lesotho, 2008-10. Nyame Akuma 74, 51-62.

Mitchell, P. J., \& Steinberg, J. (1992). Ntloana Tsoana: a Middle Stone Age sequence from western Lesotho. The South African Archaeological Bulletin, 26-33.

Moncel, M., H. (2003). Un assemblage microlithique du début du Pléistocéne supérieur en Europe Centrale. L'Anthropologie 107, 117-151.

Mortillet, A. (1896). de 1896, Les petites silex à contours géométriques trouvés en Europe, Asie et Afrique. Revue de l Ecole d anthropologie de Paris, 6, 377-405.

Mourre, V. (1996). Les industries en quartz au Paléolithique. Terminologie, méthodologie et technologie. Paléo, 8, 205-223.

Mourre, V., \& Jarry, M. (2011). Entre le marteau et l'enclume: La percussion directe au percuteur dur et la diversité de ses modalités d'application. Actes de la table ronde organisée à Toulouse du au mars. La Société des Amis du Musée National de Préhistoire et de la Recherche Archéologique avec le concours de l'Université de Toulouse le Mirail. . Toulouse: PALEO. 
Nakazawa, Y., Izuho, M., Takakura, J., \& Yamada, S. (2005). Toward an understanding of technological variability in microblade assemblages in Hokkaido, Japan. Asian Perspectives, 276-292.

Neeley, M. P. (2002). Going microlithic: A Levantine perspective on the adoption of microlithic technologies. In R. G. Elston, \& S. L. Kuhn (Eds.), Thinking Small: Global Perspectives on Microlithization (pp. 45-56). Washington, DC: American Anthropological Association.

Orliac M. (1997). Microlithe. In Leroi-Gourhan A. (ed.), Dictionaire de la préhistoire. Paris: Quadrige/PUF.

Pargeter, J. (2013). Rock type variability and impact fracture formation: Working towards a more robust macrofracture method. Journal of Archaeological Science 40, 4056-4065.

Pargeter, J., \& Duke, H. (2015). Exploring Variability in Bipolar Technology (Special edition of Lithic Technology). Vol. 40.4.

Pargeter, J., \& Redondo, M. (2015). Contextual approaches to studying unretouched bladelets: A late Pleistocene case study from Sehonghong rockshelter, Lesotho. Quaternary International 404, 30-43.

Pargeter, J., Shea, J., Utting, B. (2016). Quartz backed tools as arrowheads and hand-cast spearheads: Hunting experiments and macro-fracture analysis, Journal of Archaeological Science 73, 145-157.

Pargeter, J., de la Peña, P., Submitted. Quartz bipolar reduction and lithic miniaturization: Experimental results and archaeological implications, Journal of Field Archaeology.

Petraglia, M., Clarkson, C., Boivin, N., Haslam, M., Korisettar, R., Chaubey, G., et al. (2009). Population increase and environmental deterioration correspond with microlithic innovations in South Asia ca. 35,000 years ago. Proceedings of the National Academy of Sciences 106, 12261-12266.

Scerri, E. M., Gravina, B., Blinkhorn, J., \& Delagnes, A. (2015). Can Lithic Attribute Analyses Identify Discrete Reduction Trajectories? A Quantitative Study Using Refitted Lithic Sets. Journal of Archaeological Method and Theory, 1-23.

Schweitzer, F. R., \& Wilson, M. L. (1982). Byneskranskop 1: a late Quaternary living site in the southern Cape Province, South Africa. Annals of the South African Museum 88, 1-203.

Shea, J. J. (2008). The Middle Stone Age archaeology of the Lower Omo Valley Kibish Formation: excavations, lithic assemblages, and inferred patterns of early Homo sapiens behavior. Journal Of Human Evolution 55, 448-485.

Shea, J. J. (2014). Sink the Mousterian? Named Stone Tool Industries (NASTIES) as obstacles to investigating Hominin evolutionary relationships in the Later Middle Paleolithic Levant. Quaternary International 350, 169-179.

Shea, J.J., (2015). Making and using stone tools: advice for learners and teachers and insights for archaeologists, Lithic Technology 40, 231-248.

Shea, J. J., \& Bar-Yosef, O. (1999). Lithic Assemblages from the New (1988-1994) Excavations at 'Ubeidiya: A Preliminary Report. Journal of the Israel Prehistoric Society, 28, 5-20.

Shea, J. J., \& Sisk, M. L. (2010). Complex Projectile Technology and Homo sapiens Dispersal into Western Eurasia. PaleoAnthropology, 100-122.

Shott, M.J., (1989). Bipolar industries: Ethnographic evidence and archaeological implications, North American Archaeology 10, 1-24.

Smyth, R.B., (1878). The aborigines of Victoria, John Ferres Government Printer, Melbourne. 
Straus, L. G. (2002). Selecting Small: Microlithic Musings for the Upper Paleolithic and Mesolithic of Western Europe. In R. G. Elston, \& S. L. Kuhn (Eds.), Thinking Small: Global Perspectives on Microlithization (pp. 68-82). Washington, DC: American Anthropological Association (Archaeological Paper No. 12).

Trechmann, C., (1910). Note on the occurrence of a so-Called pygmy or midget implement made from a quartz crystal in a Neolithic lake-dwelling on the Greifensee, Near Zurich, Man $10,13-14$

Torrence, R. (1989). Re-tooling: Towards a behavioral theory of stone tools. In R. Torrence (Ed.), Time, Energy, and Stone Tools (pp. 57-66). Cambridge, UK: Cambridge University Press.

Villa, P., \& Roebroeks, W. (2014). Neandertal demise: An archaeological analysis of the modern human superiority complex. PLoS ONE 9, e96424.

Villa, P., Soriano, S., Tsanova, T., Degano, I., Higham, T. F., d'Errico, F., et al. (2012). Border

Cave and the beginning of the Later Stone Age in South Africa. PNAS 109, 13208-13213.

Wadley, L. (1993). The Pleistocene Later Stone Age south of the Limpopo River. Journal of World Prehistory 7, 243-296.

Wadley, L. (1996). The Robberg industry of Rose Cottage Cave, Eastern Free State: The technology, spatial patterns and environment. The South African Archaeological Bulletin, 51, 64-74.

Wadley, L., \& Mohapi, M. (2008). A Segment is not a Monolith: Evidence from the Howiesons Poort of Sibudu, South Africa. Journal of Archaeological Science 35, 2594-2605.

White, J. P. (1968). Fabricators, outils ecailles or scalar cores? Mankind 6, 658-666.

White, J.P., Thomas, D.H., 1972. What mean these stones? Ethno-taxonomic models and archaeological interpretations in the New Guinea Highlands, in: Clark, D.L. (Ed.), Models in Archaeology, London, pp. 275-308.

Yellen, J.E., Brooks, A.S., Cornelissen, E., Mehlman, M., Stewart, K., 1995. A Middle Stone Age Worked Bone Industry from Katanda, Upper Semliki Valley, Zaire. Science 268, 553-556.

Yesner, D. R., \& Pearson, G. (2002). Microblades and Migrations: Ethnic and Economic Models in the Peopling of the Americas. In R. G. Elston, \& S. L. Kuhn (Eds.), Thinking Small: Global Perspectives on Microlithization (pp. 133-162). Washington, DC: American Anthropological Association (Archaeological Paper No. 12).

Zaidner, Y., 2013. Adaptive flexibility of Oldowan hominins: Secondary use of flakes at Bizat Ruhama, Israel, PLoS ONE 8, e66851. 

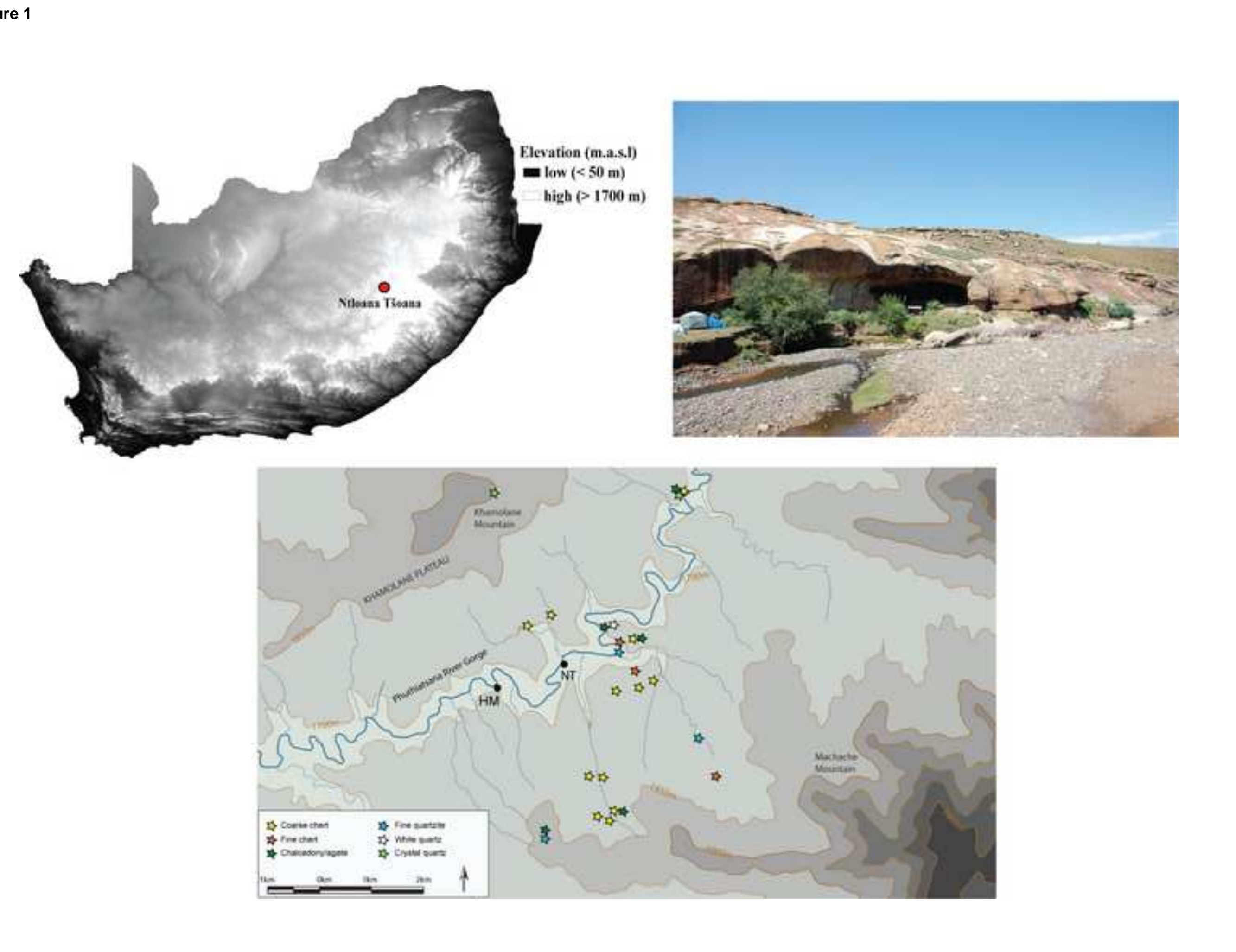

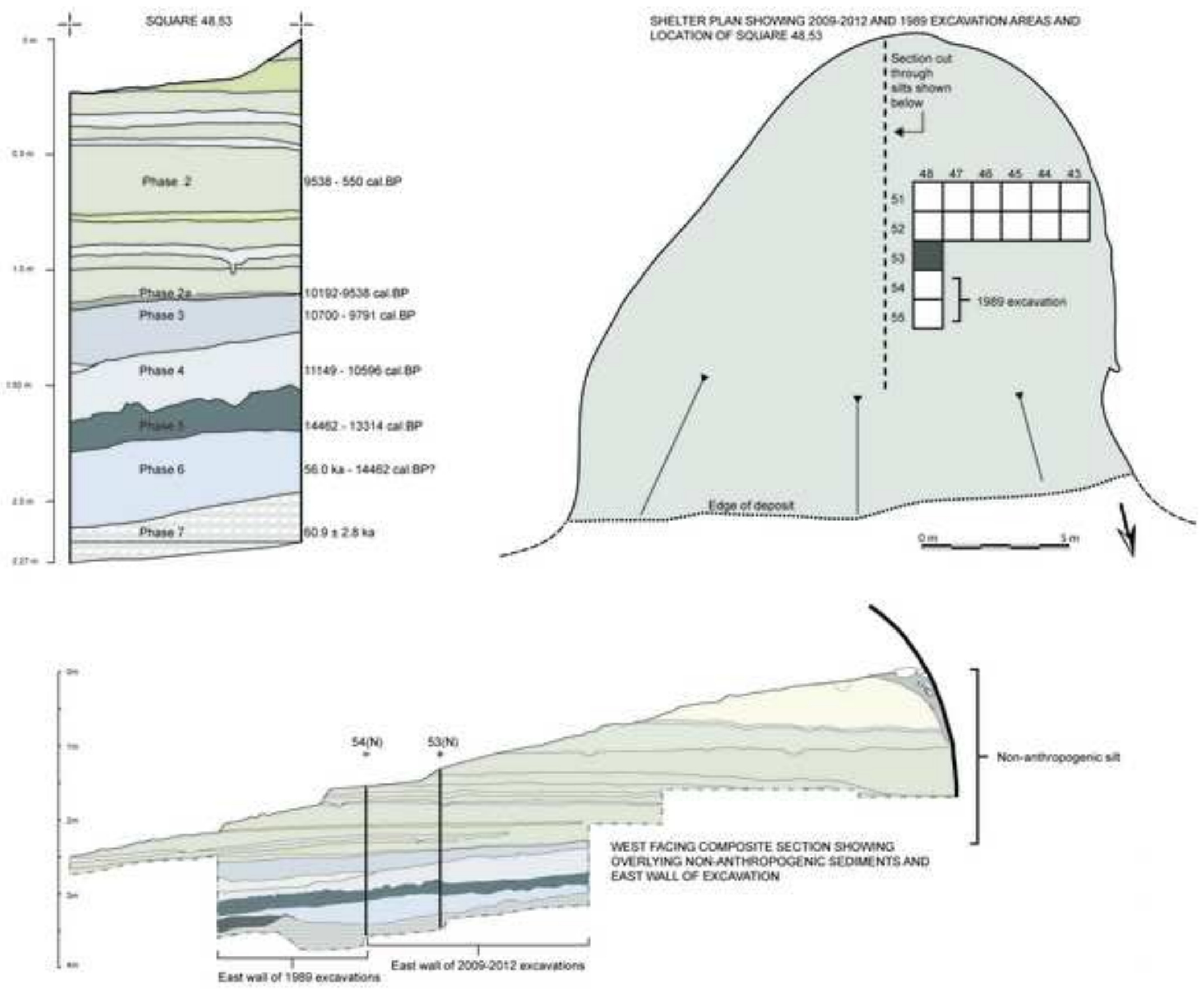

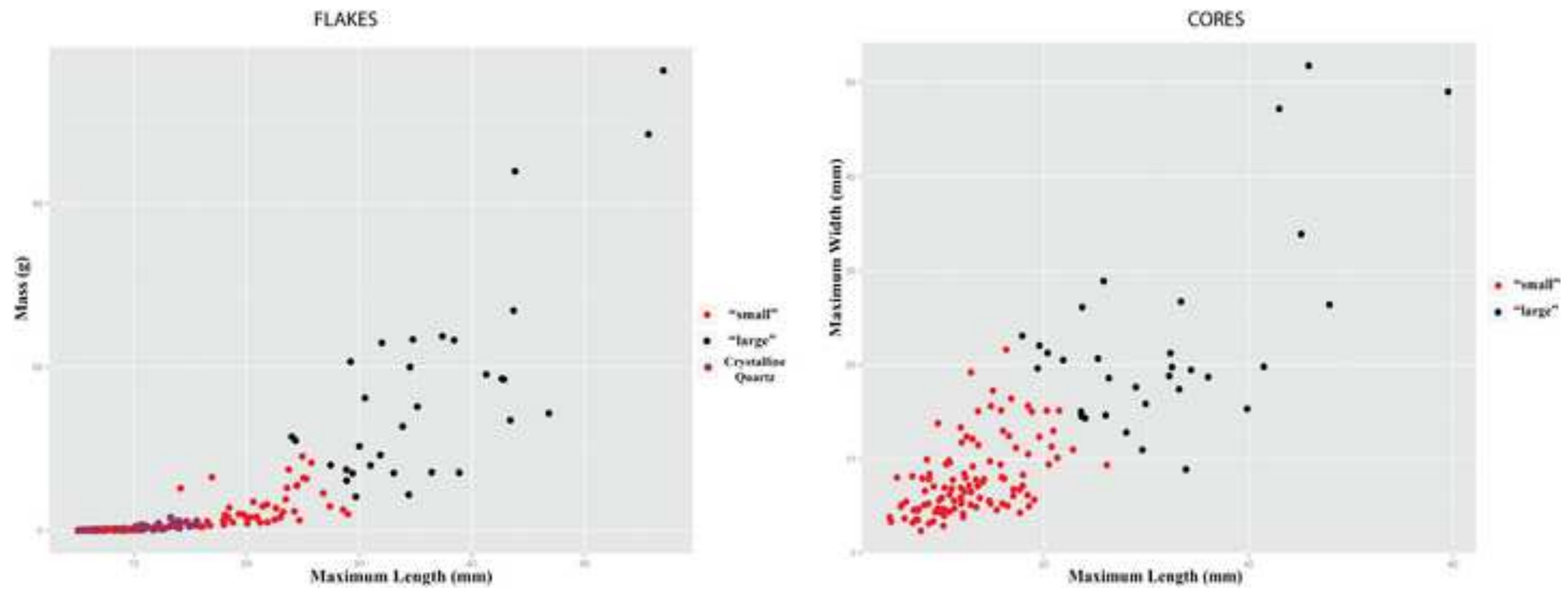

- "harger

gevirs
Tamali"

"large" 

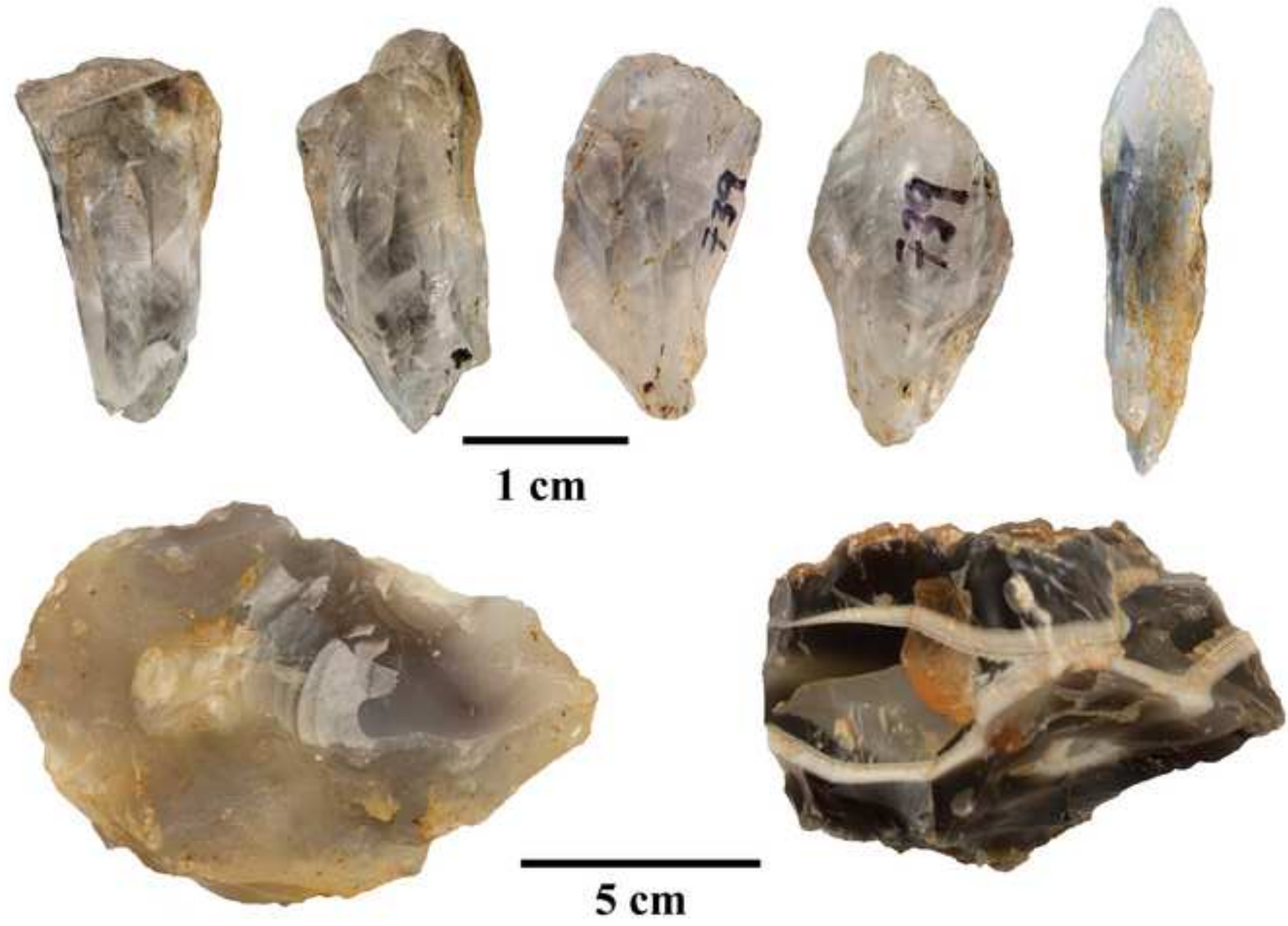

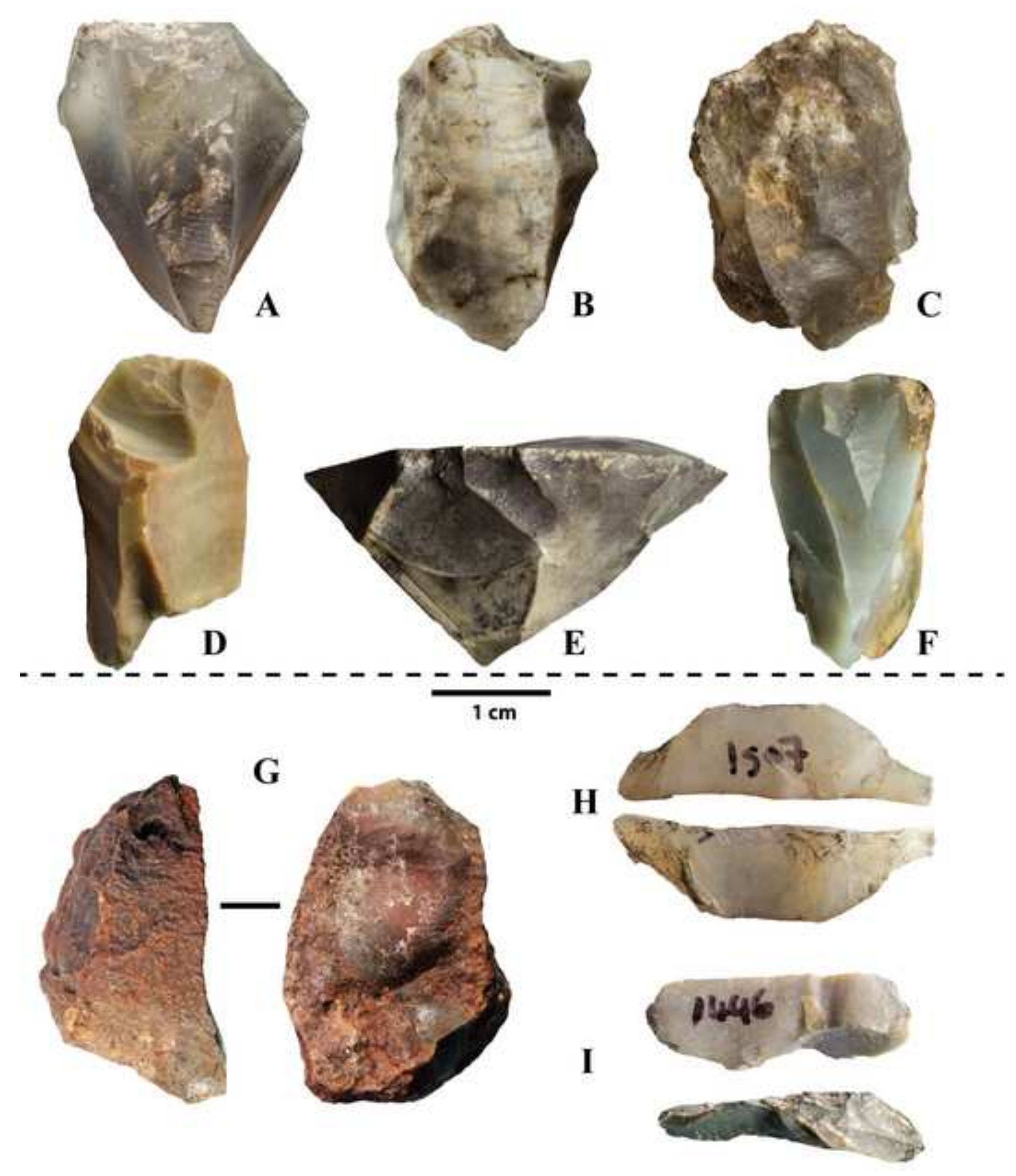

H
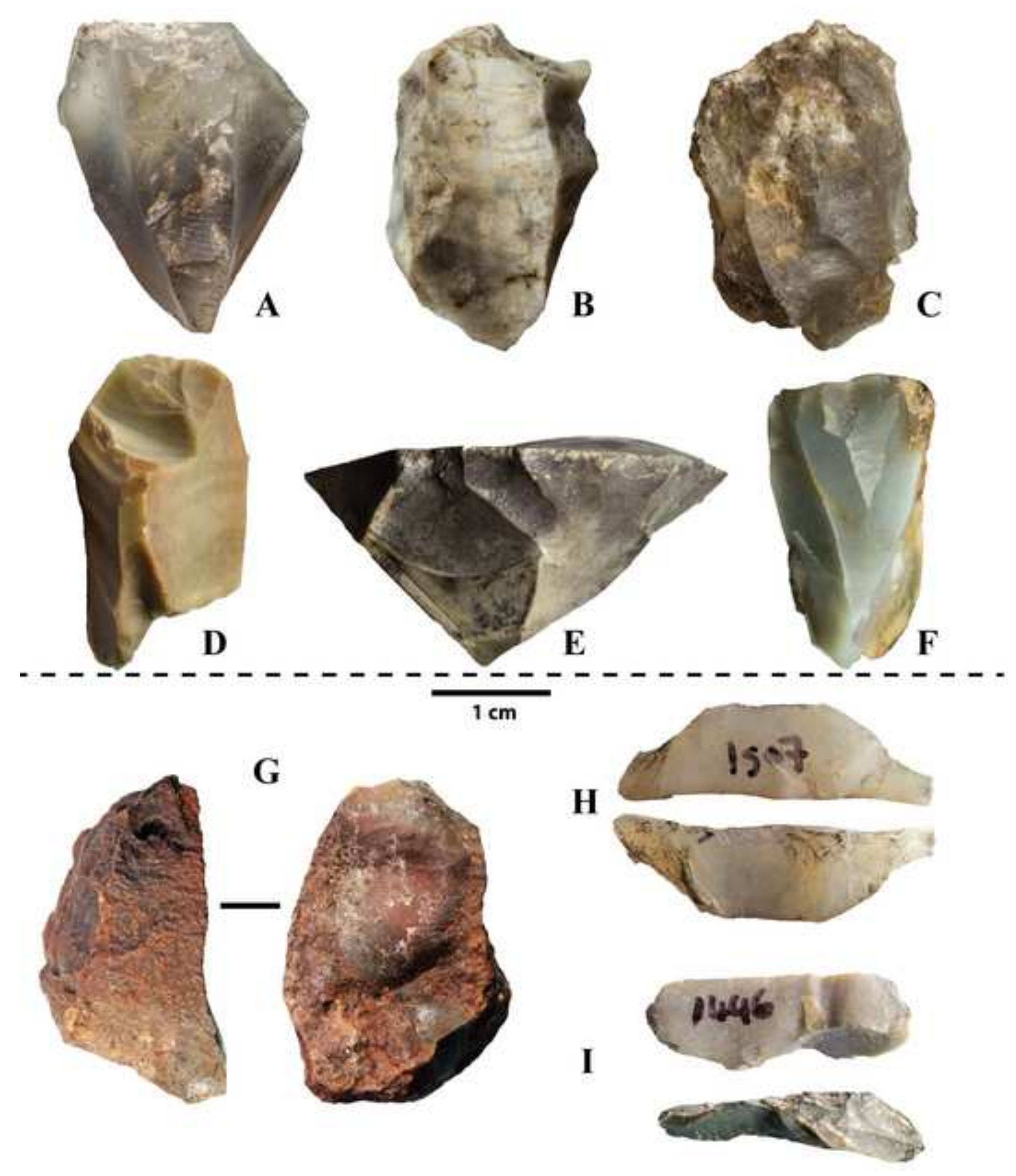

Figure 5 

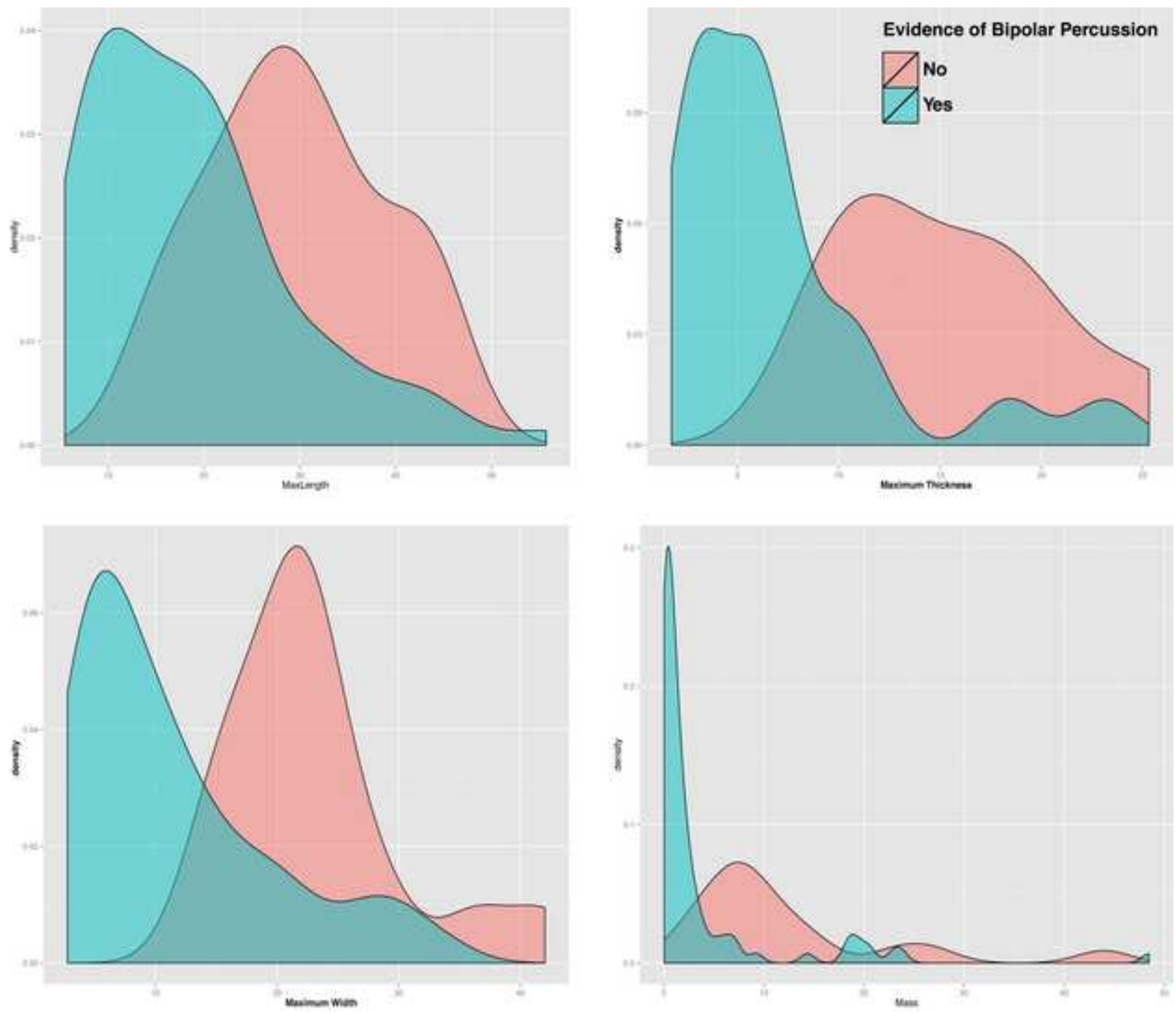


\section{Bipolar core cortex values}

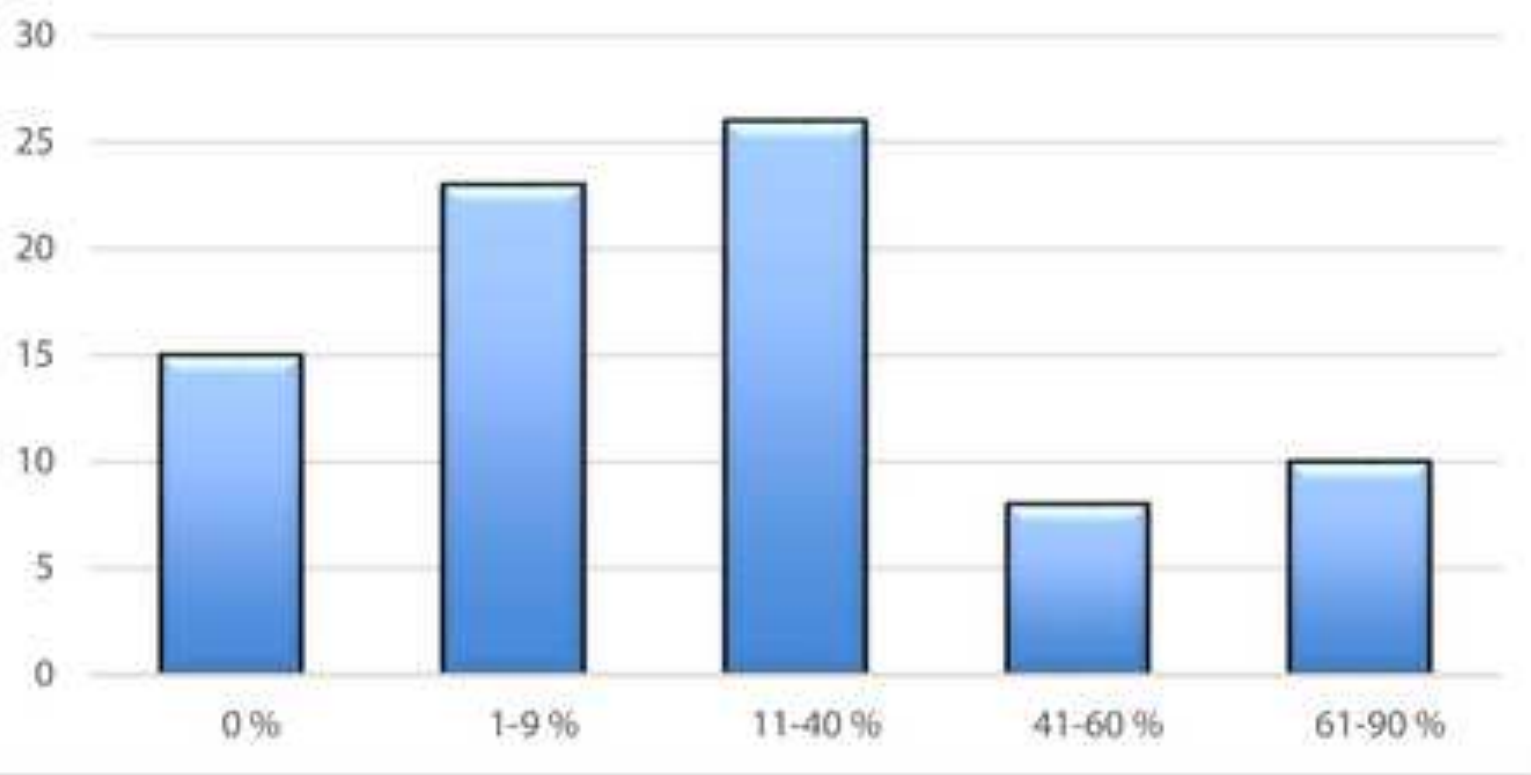



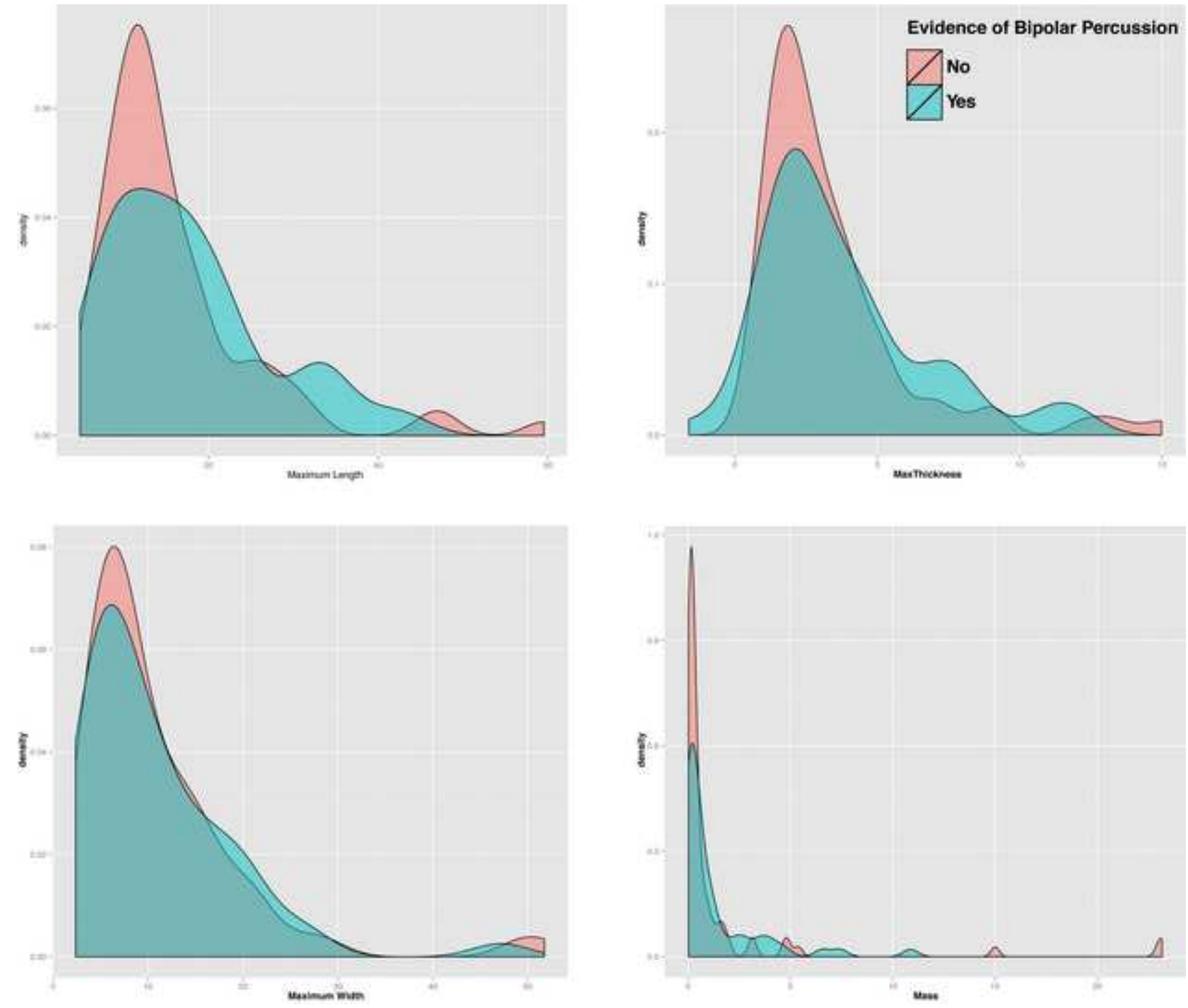

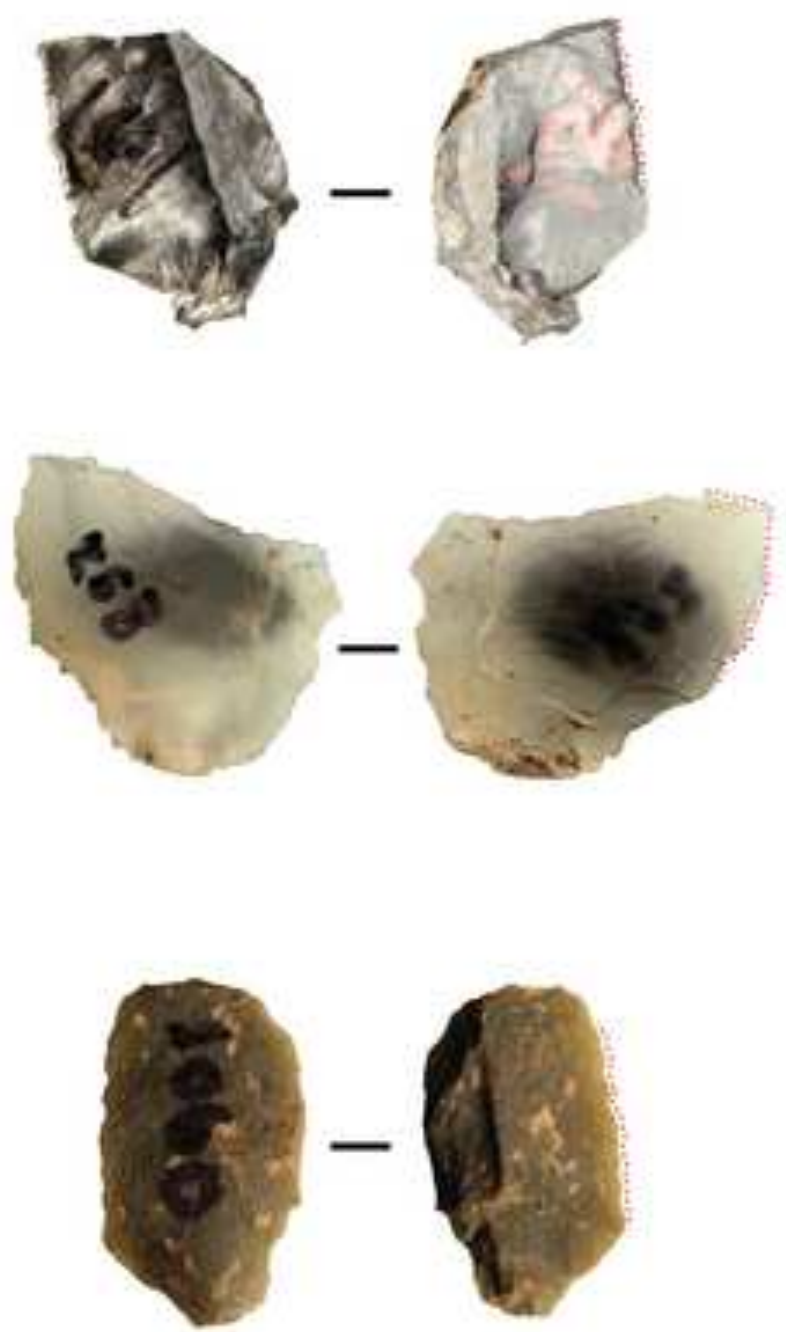
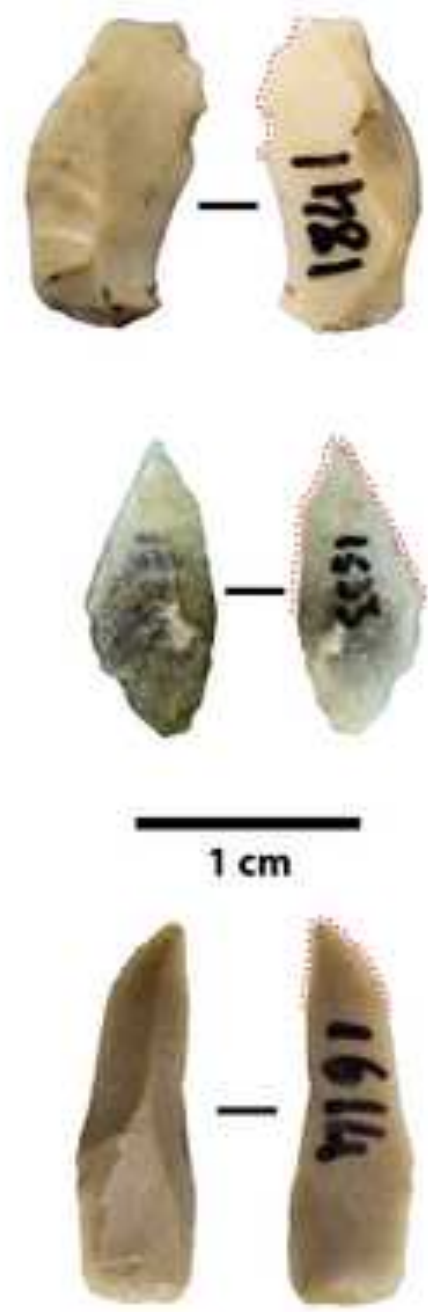
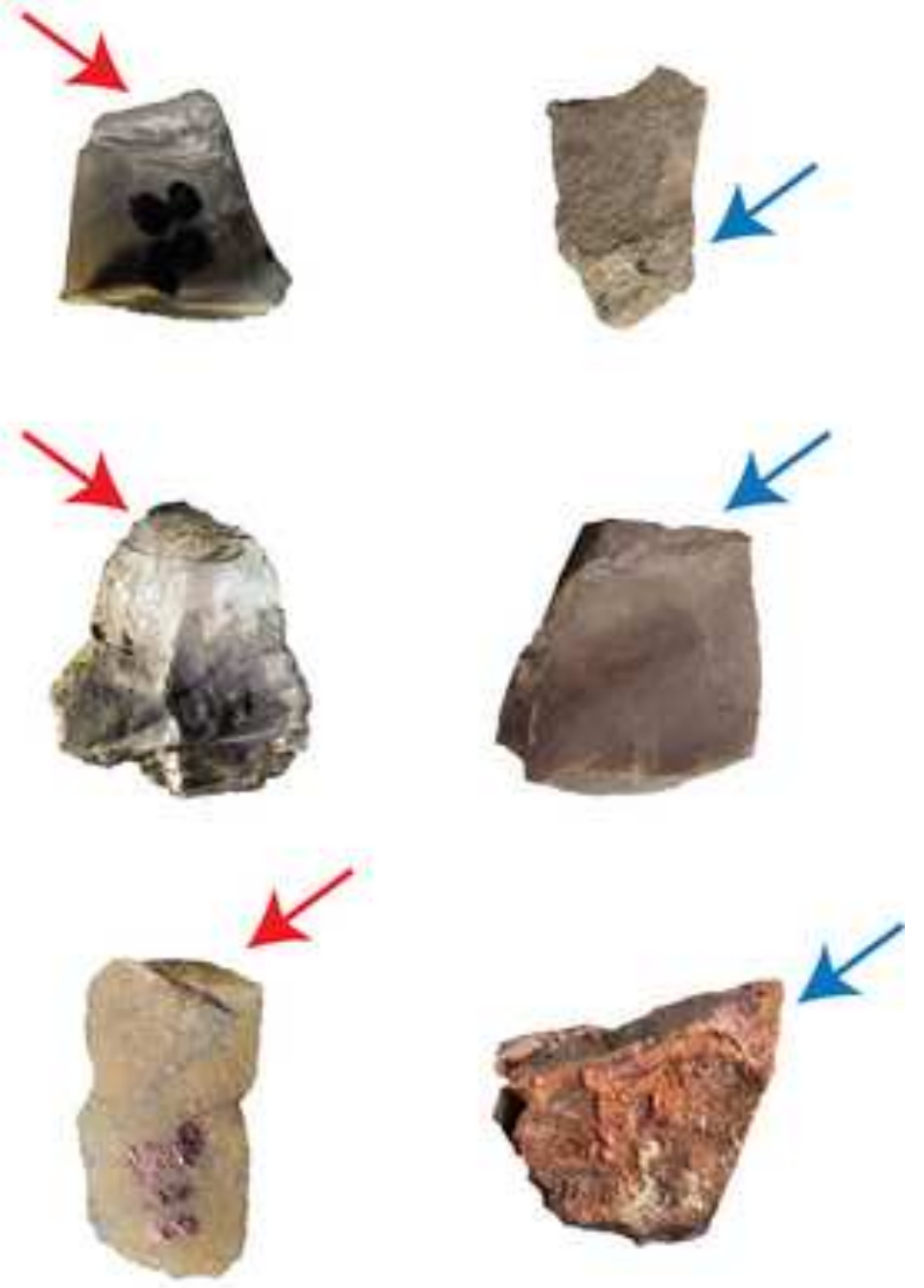

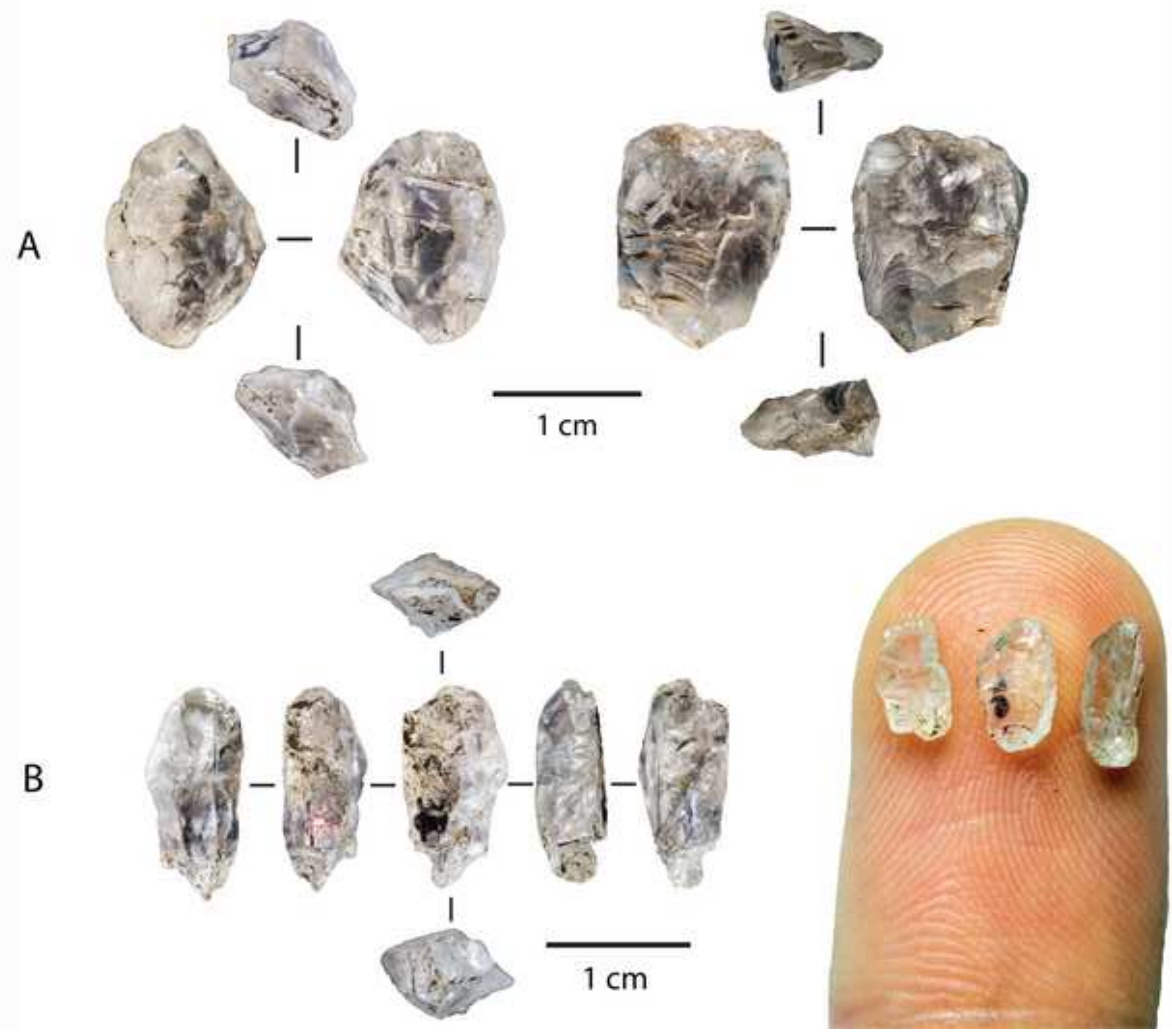
Table 1. Overview of common definitions for 'microliths'.

\begin{tabular}{|c|c|c|}
\hline Definition & Notes on size & Reference \\
\hline Small implements with "proof of design in their manufacture" & Size not specified & Honeywood 1877:180 \\
\hline Small modified geometric artefacts & Size not specified & Mortillet 1896 \\
\hline Pygmy implements: small retouched tools & 20-30 mm length, 3-4 mm width & Abbott 1913 \\
\hline $\begin{array}{l}\text { Flakes with the bulb of percussion removed and steep secondary } \\
\text { reworking }\end{array}$ & Size not specified & Clark 1933 \\
\hline $\begin{array}{l}\text { Bladelets and flakelets transformed into backed tools and small convex } \\
\text { scrapers }\end{array}$ & Length $<50 \mathrm{~mm}$ for bladelets and flakelets & Clark 1985 \\
\hline Bladelet production with low frequencies of retouched tools & Bladelets $<12 \mathrm{~mm}$ width & Deacon 1984; Mitchell 1988 \\
\hline Small retouched tools, frequently geometric & Length $<40 \mathrm{~mm}$, thickness $<4 \mathrm{~mm}$ & Orliac 1997 \\
\hline Any backed flake regardless of size & Size not a determining factor & Ambrose 1998 \\
\hline Any very small backed flake & Size not specified & Ambrose 2002 \\
\hline Any very small retouched flake (backed or not backed) & Size not specified & Belfer-Cohen \& Goring-Morris 2002 \\
\hline Small blades (or bladelets) transformed by abrupt retouch & Size not specified & Kuhn \& Elston 2002 \\
\hline Small retouched tools, frequently geometric & $<30 \mathrm{~mm}$ in length & Burdukiewicz 2005 \\
\hline Microblades and retouched geometrics & Contextual-based size cut-off & Petraglia et al. 2009 \\
\hline Systematic microblade and/or backed artefact production & Size not specified & Clarkson et al. 2009 \\
\hline Small unretouched flakes & Size not specified & Villa et al. 2012 \\
\hline Small bladelets retouched into geometrics/high frequencies of small tools & $<50 \mathrm{~mm}$ length for bladelets & Brown et al. 2012 \\
\hline Small flakes and bladelets used retouched or unretouched & Size not specified & Villa et al. 2012 \\
\hline Systematic small flake and bladelet production & Size not specified & de la Peña \& Wadley 2014 \\
\hline
\end{tabular}


Table 2. Radiocarbon dates for the phase 5 occupation at Ntloana Tšoana.

\begin{tabular}{cccccc}
\hline Context number & Technique & Sample Number & Age BP & Error & Age cal. BP \\
\hline $5-$ K9 032 & C $^{14}$ & Pta-5236 & 12110 & 120 & $14253-13314$ \\
$5-521$ & AMS & OxA-X-2460-49 & 11830 & 90 & $13784-13437$ \\
$5-538$ & AMS & UGAMS-8981 & 12800 & 30 & $14281-14001$ \\
$5-540$ & AMS & UGAMS-8982 & 12330 & 30 & $14462-14054$ \\
\hline
\end{tabular}

Table 3. Attributes used to differentiate bipolar and freehand reduction on silicate and quartz rocks. Traits follow those outlined in de la Peña \& Vega (2013), de la Peña (2015); Pargeter \& de la Peña (Submitted).

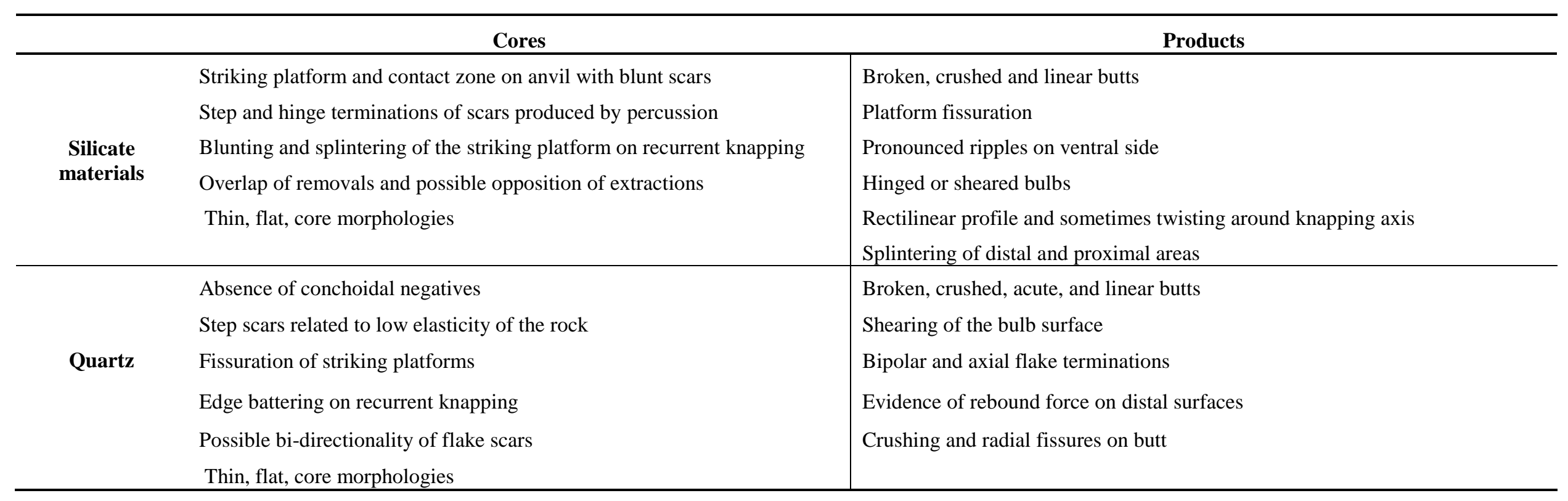


Table 4. Overview of the Ntloana Tšoana phase 5 lithics

\begin{tabular}{llrr}
\hline \multirow{4}{*}{ Cores } & n & \multicolumn{1}{c}{$\%$} \\
\hline \multirow{4}{*}{ Flakes } & Bipolar & 63 & 75.00 \\
& Freehand & 19 & 22.62 \\
& Indeterminate & 2 & 2.38 \\
\hline & Total Cores & $\mathbf{8 4}$ & $\mathbf{1 0 0}$ \\
\hline & Complete flakes & 141 & 4.56 \\
& Flake fragment & 517 & 16.72 \\
& Utilized flakes & 39 & 1.26 \\
& Retouched flakes & 10 & 0.32 \\
& Non I.D. fragments & 2385 & 77.13 \\
\hline & Total Flakes & $\mathbf{3 0 9 2}$ & $\mathbf{1 0 0}$ \\
\hline
\end{tabular}

Table 5. Upper range and maximum morphometric data for phase 5 chunks and manuports

\begin{tabular}{clrrrr}
\hline & Length $(\mathbf{m m})$ & Width $(\mathbf{m m})$ & Thickness $(\mathbf{m m})$ & Mass $(\mathbf{g})$ \\
\hline \multirow{2}{*}{ Chert, agate, chalcedony } & 3rd quantile & 23.18 & 15.55 & 10.015 & 3.235 \\
& Maximum & 72.78 & 54.93 & 34.65 & 100.97 \\
& & & & & \\
All quartz & 3rd quantile & 7.55 & 9.03 & 6.52 & 1.03 \\
& Maximum & 9.67 & 19.09 & 15.33 & 6.98 \\
\hline
\end{tabular}


Table 6. Breakdown of the phase 5 flakes in terms of freehand and bipolar reduction

\begin{tabular}{llrr}
\hline & & n & \% \\
\hline \multirow{4}{*}{ Freehand } & Complete flakes & 71 & 13.81 \\
& Flake fragments & 411 & 79.96 \\
& Retouched flakes & 2 & 0.39 \\
& Utilized flakes & 30 & 5.84 \\
\hline \multirow{3}{*}{ Bipolar } & Total & $\mathbf{5 1 4}$ & $\mathbf{1 0 0}$ \\
\hline & Complete flakes & 52 & 26.94 \\
& Flake fragments & 127 & 65.80 \\
& Retouched flakes & 6 & 3.11 \\
& Utilized flakes & 8 & 4.15 \\
\hline & Total & $\mathbf{1 9 3}$ & $\mathbf{1 0 0}$ \\
\hline
\end{tabular}


Table 7. Phase 5 cores broken down in terms of size based on cluster analysis, and by raw material.

\begin{tabular}{|c|c|c|c|c|c|}
\hline & \multirow[b]{3}{*}{ Raw material } & \multicolumn{4}{|c|}{ Cluster analysis size class } \\
\hline & & \multicolumn{2}{|c|}{$>24 \mathrm{~mm}$ length } & \multicolumn{2}{|c|}{$<24$ mm length } \\
\hline & & n & $\%$ & $\mathbf{n}$ & $\%$ \\
\hline \multirow{8}{*}{ Cores } & Agate & 1 & 1.96 & 0 & 0.00 \\
\hline & Chalcedony & 10 & 19.61 & 2 & 6.06 \\
\hline & Coarse chert & 1 & 1.96 & 0 & 0.00 \\
\hline & Crystalline quartz & 8 & 15.69 & 25 & 75.76 \\
\hline & Fine chert & 26 & 50.98 & 6 & 18.18 \\
\hline & Heterogeneous chert & 4 & 7.84 & 0 & 0.00 \\
\hline & Hornfels & 1 & 1.96 & 0 & 0.00 \\
\hline & Total Cores & 51 & 100 & 33 & 100 \\
\hline
\end{tabular}


Table 8. Phase 5 flakes broken down in terms of size based on cluster analysis, and by raw material.

\begin{tabular}{|c|c|c|c|c|c|}
\hline & \multirow[b]{3}{*}{ Raw material } & \multicolumn{4}{|c|}{ Cluster analysis size class } \\
\hline & & \multicolumn{2}{|c|}{$>5 \mathrm{~mm}$ width } & \multicolumn{2}{|c|}{$<5 \mathrm{~mm}$ width } \\
\hline & & $\mathbf{n}$ & $\%$ & $\mathbf{n}$ & $\%$ \\
\hline \multirow{11}{*}{ Flakes } & Agate & 5 & 0.8 & 0 & 0.0 \\
\hline & Chalcedony & 98 & 15.4 & 37 & 20.8 \\
\hline & Coarse chert & 68 & 10.7 & 9 & 5.1 \\
\hline & Crystalline quartz & 28 & 4.4 & 30 & 16.9 \\
\hline & Fine chert & 211 & 33.2 & 69 & 38.8 \\
\hline & Heterogeneous chert & 46 & 7.2 & 6 & 3.4 \\
\hline & Hornfels & 9 & 1.4 & 1 & 0.6 \\
\hline & Quartzite & 130 & 20.5 & 26 & 14.6 \\
\hline & Sandstone & 25 & 3.9 & 0 & 0.0 \\
\hline & Other & 15 & 2.4 & 0 & 0.0 \\
\hline & Total Flakes & 635 & 100.0 & 178 & 100.0 \\
\hline
\end{tabular}


Table 9. Dimensions of the Phase 5 crystal quartz cores.

\begin{tabular}{lrrrr}
\hline & Max Length $(\mathbf{m m})$ & Max Width $(\mathbf{m m})$ & Max Thickness $(\mathbf{m m})$ & Mass $(\mathbf{g})$ \\
\hline $\mathrm{n}$ & 33 & 33 & 33 & 33 \\
Mean & 9.11 & 5.35 & 3.24 & 0.24 \\
Median & 16.75 & 10.01 & 6.29 & 1.16 \\
Max & 15.54 & 12.27 & 6.84 & 1.17 \\
Min & 5.08 & 1.86 & 1.41 & 0.01 \\
SD & 2.90 & 2.17 & 1.48 & 0.29 \\
CV & 31.87 & 40.55 & 45.69 & 121.15 \\
\hline
\end{tabular}


Table 1. Overview of common definitions for microliths.

\begin{tabular}{|c|c|c|}
\hline Definition & Notes on size & Reference \\
\hline Small implements with "proof of design in their manufacture" & Size not specified & Honeywood 1877:180 \\
\hline Small modified geometric artefacts & Size not specified & Mortillet 1896 \\
\hline Pygymy implements: small retouched tools & 20-30 mm length, 3-4 mm width & Abbott 1913 \\
\hline $\begin{array}{l}\text { Flakes with the bulb of percussion removed with steep secondary } \\
\text { reworking }\end{array}$ & Size not specified & Clark 1933 \\
\hline $\begin{array}{l}\text { Bladelets and flakelets transformed into backed tools and small convex } \\
\text { scrapers }\end{array}$ & $\begin{array}{l}\text { Length }<50 \mathrm{~mm} \text { for bladelets and flakelets, } \\
\text { 'small' tools can be any size }\end{array}$ & Clark 1985 \\
\hline Bladelet production with low frequencies of retouched tools & Bladelets $<12 \mathrm{~mm}$ width & Deacon 1984; Mitchell 1988 \\
\hline Small retouched tools, frequently geometric & Length $<40 \mathrm{~mm}$, thickness $<4 \mathrm{~mm}$ & Orliac 1997 \\
\hline Any backed flake regardless of size & Size not a determining factor & Ambrose 1998 \\
\hline Any very small backed flake & Size not specified & Ambrose 2002 \\
\hline Any very small retouched flakes backed or not & Size not specified & Belfer-Cohen \& Goring-Morris 2002 \\
\hline Small blades (bladelet) transformed by abrupt retouch & Size not specified & Kuhn \& Elston 2002 \\
\hline Small retouched tools, frequently geometric & $<30 \mathrm{~mm}$ in length & Burdukiewicz 2005 \\
\hline Microblades and retouched geometrics & Contextual-based & Petraglia et al. 2009 \\
\hline Systematic microblade and/or backed artefact production & Size not specified & Clarkson et al. 2009 \\
\hline Small unretouched flakes & Size not specified & Villa et al. 2012 \\
\hline $\begin{array}{l}\text { Small bladelets retouched into geometrics, or high frequencies of small } \\
\text { tools }\end{array}$ & $<50 \mathrm{~mm}$ length for bladelets & Brown et al. 2012 \\
\hline Small flakes and bladelets used retouched or unretouched & Size not specified & Villa et al. 2012 \\
\hline Systematic small flake and bladelet production & Size not specified & de la Peña \& Wadley 2014 \\
\hline
\end{tabular}


Table 2. Radiocarbon dates for the phase 5 occupation at Ntloana Tšoana.

\begin{tabular}{cccccc}
\hline Context number & Technique & Sample Number & Age BP & Error & Age cal. BP \\
\hline $5-$ K9 032 & C & Pta-5236 & 12110 & 120 & $14253-13314$ \\
$5-521$ & AMS & OxA-X-2460-49 & 11830 & 90 & $13784-13437$ \\
$5-538$ & AMS & UGAMS-8981 & 12800 & 30 & $14281-14001$ \\
$5-540$ & AMS & UGAMS-8982 & 12330 & 30 & $14462-14054$ \\
\hline
\end{tabular}

Table 3. Attributes used to differentiate bipolar and freehand reduction on silicate and quartz rocks. Traits follow those outlined in de la Peña \& Vega (2013), de la Peña (2015); Pargeter \& de la Peña (Submitted).

\begin{tabular}{|c|c|c|}
\hline & Cores & Products \\
\hline Silicate materials & $\begin{array}{l}\text { Striking platform and contact zone on anvil with blunt scars } \\
\text { Step and hinge terminations of scars produced by percussion } \\
\text { Blunting and splintering of the striking platform on recurrent knapping } \\
\text { Overlap of removals and possible opposition of extractions }\end{array}$ & $\begin{array}{l}\text { Broken, crushed and linear butts } \\
\text { Platform fissuration } \\
\text { Pronounced ripples on ventral side } \\
\text { Hinged or sheared bulb } \\
\text { Rectilinear profile and sometimes twisting around knapping axis } \\
\text { Splintering of distal and proximal areas }\end{array}$ \\
\hline Quartz & $\begin{array}{l}\text { Absence of conchoidal negatives } \\
\text { Step scars related to low elasticity of the rock } \\
\text { and fissuration of striking platforms } \\
\text { Edge battering on recurrent knapping } \\
\text { Possible opposition of extractions }\end{array}$ & $\begin{array}{l}\text { Broken, crushed, acute, and linear butts } \\
\text { Shearing of the bulb surface } \\
\text { Bipolar and axial flake terminations } \\
\text { Evidence of rebound force on distal surfaces } \\
\text { Crushing and radial fissures on butt }\end{array}$ \\
\hline
\end{tabular}


Table 4. Overview of the Ntloana Tšoana phase 5 lithics

\begin{tabular}{llrr}
\hline \multirow{4}{*}{ Cores } & \multicolumn{1}{c}{ n } & \multicolumn{1}{c}{ \% } \\
\hline \multirow{4}{*}{ Flakes } & Bipolar & 63 & 75.00 \\
& Freehand & 19 & 22.62 \\
& Indeterminate & 2 & 2.38 \\
\hline & Total Cores & $\mathbf{8 4}$ & $\mathbf{1 0 0}$ \\
\hline & Complete flakes & 141 & 4.56 \\
& Flake fragment & 517 & 16.72 \\
& Utilized flakes & 39 & 1.26 \\
& Retouched flakes & 10 & 0.32 \\
& Non I.D. fragments & 2385 & 77.13 \\
\hline & Total Flakes & $\mathbf{3 0 9 2}$ & $\mathbf{1 0 0}$ \\
\hline
\end{tabular}

Table 5. Upper range and maximum morphometric data for phase 5 chunks and manuports

\begin{tabular}{clrrrr}
\hline & & Length $(\mathbf{m m})$ & Width $(\mathbf{m m})$ & Thickness (mm) & Mass (g) \\
\hline \multirow{2}{*}{ Chert, agate, chalcedony } & 3rd quantile & 23.18 & 15.55 & 10.015 & 3.235 \\
& Maximum & 72.78 & 54.93 & 34.65 & 100.97 \\
& & & & & \\
All quartz & 3rd quantile & 7.55 & 9.03 & 6.52 & 1.03 \\
& Maximum & 9.67 & 19.09 & 15.33 & 6.98 \\
\hline
\end{tabular}


Table 6. Breakdown of the phase 5 flakes in terms of freehand and bipolar reduction

\begin{tabular}{rlrr}
\hline & & n & \multicolumn{1}{c}{ \% } \\
\hline \multirow{4}{*}{ Freehand } & Complete flakes & 71 & 13.81 \\
& Flake fragments & 411 & 79.96 \\
& Retouched flakes & 2 & 0.39 \\
& Utilized flakes & 30 & 5.84 \\
\hline \multirow{4}{*}{ Bipolar } & Total & $\mathbf{5 1 4}$ & $\mathbf{1 0 0}$ \\
\hline & Complete flakes & 52 & 26.94 \\
& Flake fragments & 127 & 65.80 \\
& Retouched flakes & 6 & 3.11 \\
& Utilized flakes & 8 & 4.15 \\
\hline & Total & $\mathbf{1 9 3}$ & $\mathbf{1 0 0}$ \\
\hline
\end{tabular}


Table 7. Phase 5 cores broken down in terms of size based on cluster analysis, and by raw material.

\begin{tabular}{|c|c|c|c|c|c|}
\hline & \multirow[b]{3}{*}{ Raw material } & \multicolumn{4}{|c|}{ Cluster analysis size class } \\
\hline & & \multicolumn{2}{|c|}{ > $24 \mathrm{~mm}$ length } & \multicolumn{2}{|c|}{$<24$ mm length } \\
\hline & & $\mathbf{n}$ & $\%$ & $\mathbf{n}$ & $\%$ \\
\hline \multirow{8}{*}{ Cores } & Agate & 1 & 1.96 & 0 & 0.00 \\
\hline & Chalcedony & 10 & 19.61 & 2 & 6.06 \\
\hline & Coarse Chert & 1 & 1.96 & 0 & 0.00 \\
\hline & Crystalline Quartz & 8 & 15.69 & 25 & 75.76 \\
\hline & Fine Chert & 26 & 50.98 & 6 & 18.18 \\
\hline & Heterogenous Chert & 4 & 7.84 & 0 & 0.00 \\
\hline & Hornfels & 1 & 1.96 & 0 & 0.00 \\
\hline & Total Cores & 51 & 100 & 33 & 100 \\
\hline
\end{tabular}


Table 8. Phase 5 flakes broken down in terms of size based on cluster analysis, and by raw material.

\begin{tabular}{|c|c|c|c|c|c|}
\hline & \multirow[b]{3}{*}{ Raw material } & \multicolumn{4}{|c|}{ Cluster analysis size class } \\
\hline & & \multicolumn{2}{|c|}{ > $18 \mathrm{~mm}$ length } & \multicolumn{2}{|c|}{ < $18 \mathrm{~mm}$ length } \\
\hline & & $\mathbf{n}$ & $\%$ & $\mathbf{n}$ & $\%$ \\
\hline \multirow{11}{*}{ Flakes } & Agate & 5 & 0.8 & 0 & 0.0 \\
\hline & Chalcedony & 98 & 15.4 & 37 & 20.8 \\
\hline & CoarseChert & 68 & 10.7 & 9 & 5.1 \\
\hline & CrystallineQuartz & 28 & 4.4 & 30 & 16.9 \\
\hline & FineChert & 211 & 33.2 & 69 & 38.8 \\
\hline & HeterogenousChert & 46 & 7.2 & 6 & 3.4 \\
\hline & Hornfels & 9 & 1.4 & 1 & 0.6 \\
\hline & Quartzite & 130 & 20.5 & 26 & 14.6 \\
\hline & Sandstone & 25 & 3.9 & 0 & 0.0 \\
\hline & Other & 15 & 2.4 & 0 & 0.0 \\
\hline & Total Flakes & 635 & 100.0 & 178 & 100.0 \\
\hline
\end{tabular}


Table 9. Dimensions of the Phase 5 crystal quartz cores.

\begin{tabular}{lrrrr}
\hline & Max Length & Max Width & Max Thickness & \multicolumn{1}{c}{ Mass } \\
\hline $\mathrm{n}$ & 33 & 33 & 33 & 33 \\
Mean & 9.11 & 5.35 & 3.24 & 0.24 \\
Median & 16.75 & 10.01 & 6.29 & 1.16 \\
Max & 15.54 & 12.27 & 6.84 & 1.17 \\
Min & 5.08 & 1.86 & 1.41 & 0.01 \\
SD & 2.90 & 2.17 & 1.48 & 0.29 \\
CV & 31.87 & 40.55 & 45.69 & 121.15 \\
\hline
\end{tabular}

